\title{
Fiscal Institutions in Germany
}

\author{
Heiko T. Burret a and Lars P. Feld ${ }^{\mathrm{b}}$
}

JEL-Classification: H30, H60, H72

Keywords: Fiscal Federalism, German Debt Brake, Fiscal Compact

\begin{abstract}
It is very tempting to a minister to employ such an expedient [public debt], as enables him to make a great figure during his administration, without overburthening the people with taxes, or exciting any immediate clamours against himself. The practice, therefore, of contracting debt will almost infallibly be abused, in every government.

David Hume (1741).
\end{abstract}

\section{Introduction}

In 2009, Germany revised its constitutional provisions for restricting public debt. This reform was the first revision since 1969 and it aimed at curing the shortcomings of the previous rules. German constitutions had restricted public debt since the foundation of the German Empire, the Kaiserreich, in 1871. Article 73 RV of the German Empire had stipulated that only in extraordinary circumstances, government bonds could be issued. Regularly, revenue and surpluses from previous years had to cover spending (Article 69 et sequ. RV). The German Laender in these earlier times had been fully autonomous and responsible for their government finances. In Article 87 the Weimar Constitution allowed for government debt only extraordinarily and only in order to finance expenditures that generated returns. In 1933, these constitutional debt restrictions were suspended, but the German Basic Law (Grundgesetz) adopted the same provisions after the Second World War. The Laender had similar provisions.

The reform of 1969 introduced more flexibility into these debt restrictions. According to Article 115 GG (Basic Law) old version, the federal government could incur public debt up to the amount of gross public investment. But in recessions - more exactly: when a disturbance of the (macro-) economic equilibrium

a Walter Eucken Institut, Goethestrasse 10, 79100 Freiburg, Germany, Phone +49.761.790970, Fax+49.761.79097-97, burret@eucken.de.

b Walter Eucken Institut and Albert-Ludwigs-University Freiburg, Goethestrasse 10, 79100 Freiburg, Germany, Phone+49.761.79097-0, Fax+49.761.79097-97, feld@eucken.de. 
occurs - government debt could be higher. Only much later, on April 18, 1989 and on July 9, 2007, the German Constitutional Court specified this clause further by demanding that the government must spell out clearly the existence of a macro-economic disequilibrium and must show that the additional government debt is suitable for correcting the disequilibrium (BVerfGE 79, 311; 119, 96). The possibility to incur higher debt for deficit spending in recessions was introduced at a time when the belief in the effectiveness of Keynesian countercyclical policies was at its peak in Germany. Policymakers were not concerned at all about possibly increasing public debt.

This has changed since, as public debt in Germany has increased markedly during the past four decades. It has meanwhile arrived at levels that are unsustainable in the long-run (Burret, Feld and KöHler, 2013). In Section 2 of this paper, we illustrate this situation of public finances in Germany. The reasons that have led to the continuing trend in increasing indebtedness not only in Germany, but also in other countries are outlined in Section 3. The shortcomings of the aforementioned old debt restrictions of the German Grundgesetz introduced in 1969 are discussed in Section 4. The new debt brake that passed in 2009 is analyzed in Section 5 and the necessary changes of this new rule that are induced by the Fiscal Compact of the Eurozone member countries are discussed in Section 6. Section 7 concludes.

\section{Public Debt in Germany}

The development of general public debt in percent of GDP, as depicted by Figure 1, reveals six recurring issues concerning government debt: (I) the debt ratio peaked in war times. During WWI and WWII incurring higher debt for war finance was particularly feasible since the Reichsbank monetized public finances. Following the wars a reduction of debt was accomplished by a combination of defaults, inflation and currency reforms instead of consolidation (BURRET, Feld and KöHLER, 2013). (II) In the long peacetime period following the Second World War, public borrowing was not less of an issue. Since the early 1970s public debt in Germany increased significantly and induced a break-up of the socialliberal coalition. (III) Public debt particularly rises in recessions (shaded areas in Figure 1). While the increase of budget deficits due to automatic stabilizers may be considered as unavoidable in a recession, it is remarkable that governments do not manage to run budget surpluses in booms. (IV) On the contrary, fiscal consolidation has not even happened during times of high public revenue. Indeed, the debt ratio in Germany has hardly ever returned to its pre-recession level 


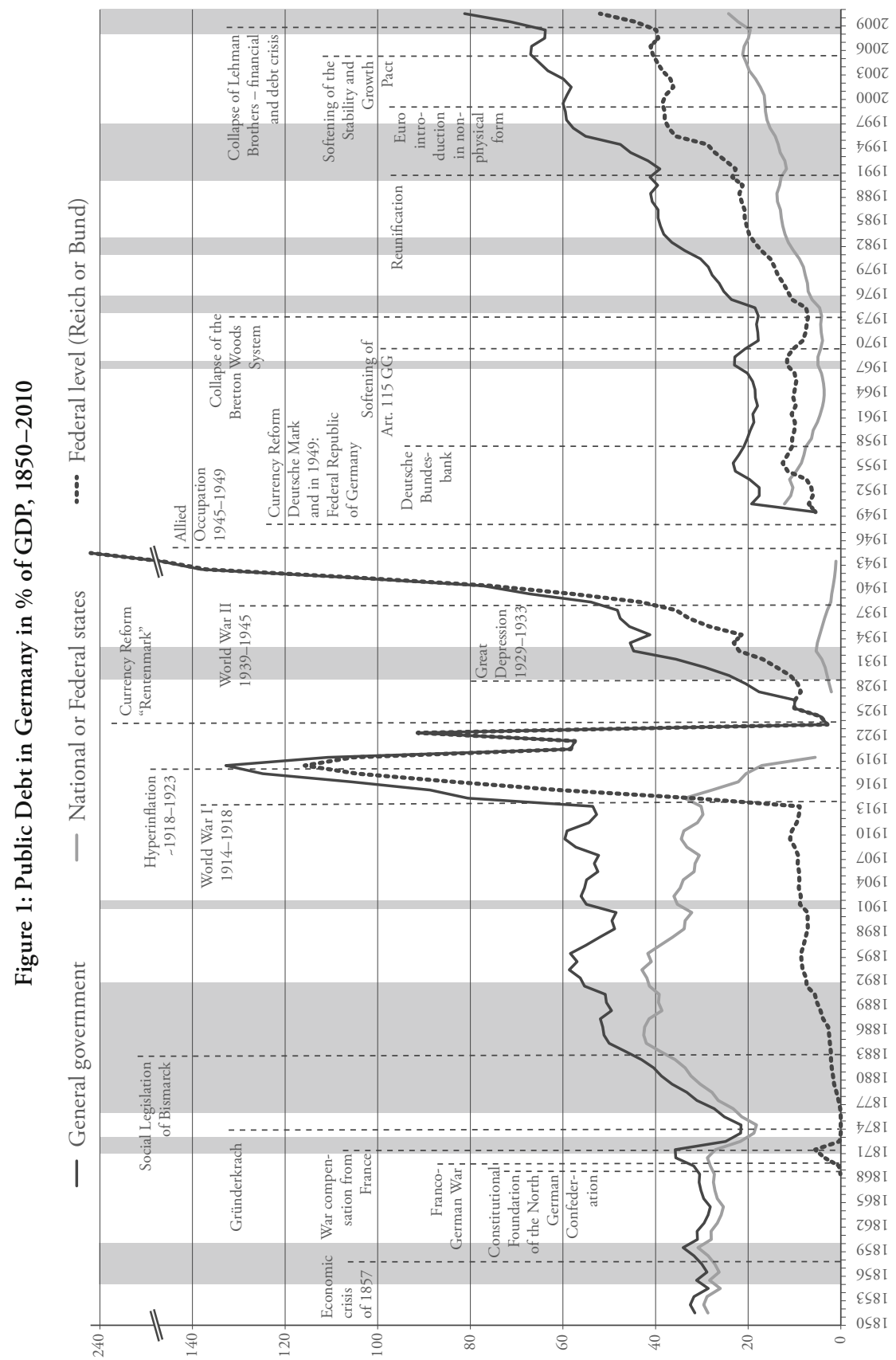

Swiss Journal of Economics and Statistics, 2013, Vol. 149 (2) 
Note to Figure 1: Periods of low real GDP growth are indicated by shaded areas (except for war times). Missing data: 1945-1948; for 1920-1926 and 1944-1949 no data for states; for 1915-1926 and 1940-1945 no data for municipalities. Before 1949 fiscal year ends 31st March/1st April. The reference date for 1923 is 15 th November. In 1945 debt refers to the level at the end of World War II. General government data includes federal, state and local tiers; since 1954, it includes Federal Special Funds; since 2006, it includes most, and since 2010, all public funds, institutions and companies. Federal level data includes the Mefo bills for 1932-1944.

Source: Burret, Feld and Köhler (2013).

afterwards. (V) The annual accumulation of fiscal deficits led to (ever) increasing debt levels. In 2010 the German debt-to-GDP ratio set a peacetime record. (VI) The development of public debt is surprising since fiscal rules restricting debt and deficits, respectively, have been in place since the formation of the German Empire. Hence, flaws in the fiscal rules are likely to have existed.

The accumulation of government debt was, however, not restricted to a certain government level. In 2011 over two thirds of general public debt was federal, while local public debt only played a minor role (6\%). Back in 1973 the municipal and federal layers were responsible each for about $40 \%$ of total public debt. While the share of general public debt of the Laender (states) was about $20 \%$ during the 1960 s, it rose to $30 \%$ in the following decade and remained around this level until today. Thus, the federal government and the Laender have mainly contributed to the increase in public debt in Germany.

The current situation of sub-federal public finances is worth a closer look: While public debt is not much of an issue in some jurisdictions, public finances are hardly sustainable in others. In 2011 Saarland and Bremen showed the largest per capita deficits, which amounted to $15 \%$ and $17 \%$ of their total expenditures, respectively. Rhineland-Palatinate and Hesse experienced a similar deterioration in their public finances ( $9 \%$ and $11 \%$ ). This development seems particularly remarkable since public revenues arrived at historical highs in 2011. The deficit accumulation led to increasing debt levels in most states. Only Saxony and Bavaria showed debt-to-GDP ratios (including municipal debt) below 20\% in 2011 (Figure 2). While Baden-Wuerttemberg was still part of this "group" back in 2006, it experienced a sharp increase in its debt ratio since then - similar to the fiscal development of most other states. In terms of debt-to-GDP the city states, Saarland, North Rhine-Westphalia, Schleswig-Holstein, RhinelandPalatinate and Saxony-Anhalt are currently most troubled. A crucial part of the Laender budgets is, thus, captured by interest payments. These costs add up to 600 Euros per inhabitant in Saarland and to almost 1000 Euros in Bremen (Deutsche Bundesbank, 2012a). 
Figure 2: State (Grey) and Municipal Debt (Black) Including Cash Advances in \% of Imputed GDP

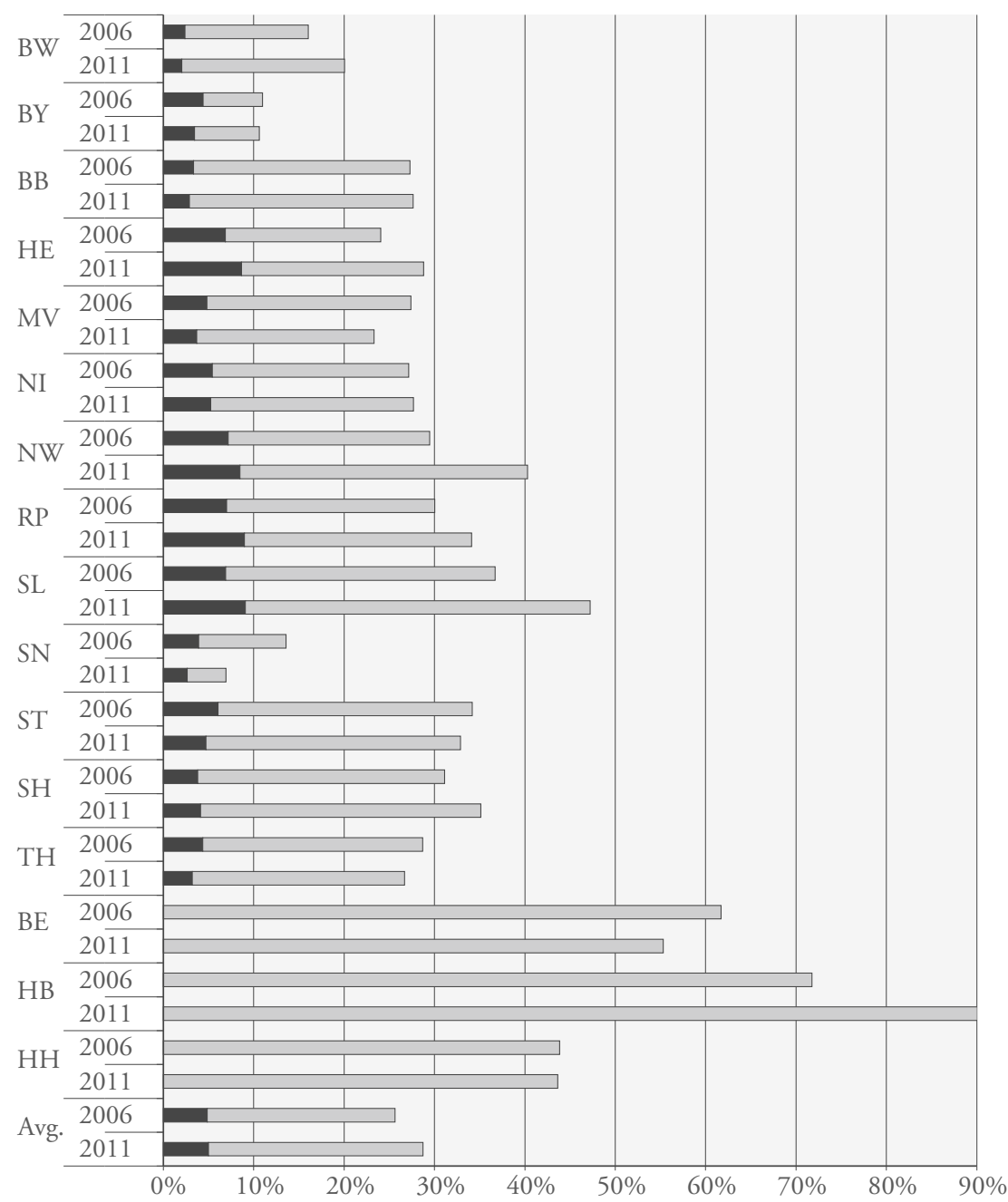

Note: The imputed GDP is calculated by multiplication of the GDP per capita in Germany with the population in the respective state. Abbreviations of the German federal states according to ISO 3166: $\mathrm{BW}=$ Baden-Wuerttemberg, $\mathrm{BY}=$ Bavaria, $\mathrm{BB}=$ Brandenburg, $\mathrm{HE}=$ Hesse, $\mathrm{MV}=$ Mecklenburg-West Pomerania, $\mathrm{NI}=$ Lower Saxony, $\mathrm{RP}=$ Rhineland-Palatinate, $\mathrm{SL}=$ Saarland, $\mathrm{SN}=$ Saxony, $\mathrm{ST}=$ Saxony Anhalt, $\mathrm{SH}=$ Schleswig-Holstein, $\mathrm{TH}=$ Thuringia, $\mathrm{BE}=$ Berlin, $\mathrm{HB}=$ Free Hanseatic City of Bremen, $\mathrm{HB}=$ Free and Hanseatic City of Hamburg.

Source: Statistisches Bundesamt. 
While local public debt is not much of an issue in the aggregate, the fiscal situation varies considerably across local jurisdictions. In several Laender, the municipalities increasingly rely on cash advances (Figure 3). Technically the communities are only allowed for borrowing for investment related expenditures. Short term loans for current consumption are merely permitted to temporarily bridge liquidity gaps between financial outflows and the corresponding revenue inflows during a single year. Yet, many municipalities face structural deficits and are, thus, using cash advances in order to finance consumptive spending in the long run. The heavy use of short term borrowing places an additional burden on local finances since interest rates on those loans are mostly less favourable as compared to long-term lending (Heinemann et al., 2009). In 2011 the amount of municipal cash advances arrived at an all-time high of 44 billion Euros. The indebtedness of the municipalities in Saarland, Rhineland-Palatinate and North RhineWestphalia roughly doubled in 2011 when adding cash advances (Figure 3). The amount of outstanding cash advances in Hesse has increased by almost 100\% since 2008. The heavy use of short term loans is at least partly shaped by the lack of local tax autonomy and an inability to reduce social spending, which is mainly determined by the federal level. In light of the deterioration in local finances, many federal states, e.g. Saxony-Anhalt, Lower Saxony, North Rhine-Westphalia, Hesse, Schleswig-Holstein and Rhineland-Palatinate, have set up (partial) bailout funds for their communities and cities (ENDERLein et al., 2012; Deutsche BANK RESEARCH, 2010).

Given the almost steady increase in public debt levels, the sustainability of public finances in Germany seems at least questionable. According to Domar (1944) public finances remain "within manageable limits" as long as the debt-toGDP ratio is not increasing across time. By assuming that maturing debts and interests are covered by issuing new government bonds, the public debt ratio is sustainable in the long run if primary budgets are balanced and the growth rate of nominal GDP exceeds or equals the nominal interest rate on government bonds. ${ }^{1}$ While Germany has achieved primary surpluses in some years, the growth rate of GDP was below the interest rate in most of the years (Figure 4). In fact, the average interest rate on governments bonds is, at least since the legal softening of the constitutional deficit limit in May 1969, below the average rate of GDP growth. Hence, public finances in Germany are hardly sustainable and a consolidation seems inevitable. In line with these findings Burret, Feld and KöHLER

1 This can be illustrated formally: $d_{t}+\left(1+i_{t}\right) /\left(1+y_{t}\right) * b_{t-1}=b_{t}$, where $d$ is the primary budget to GDP ratio, $b$ is the debt to GDP ratio, $i$ indicates the nominal interest rate, $y$ denotes the nominal growth rate and $t$ the time. 
Figure 3: Share of Cash Advances on Total Municipal Debt in \%
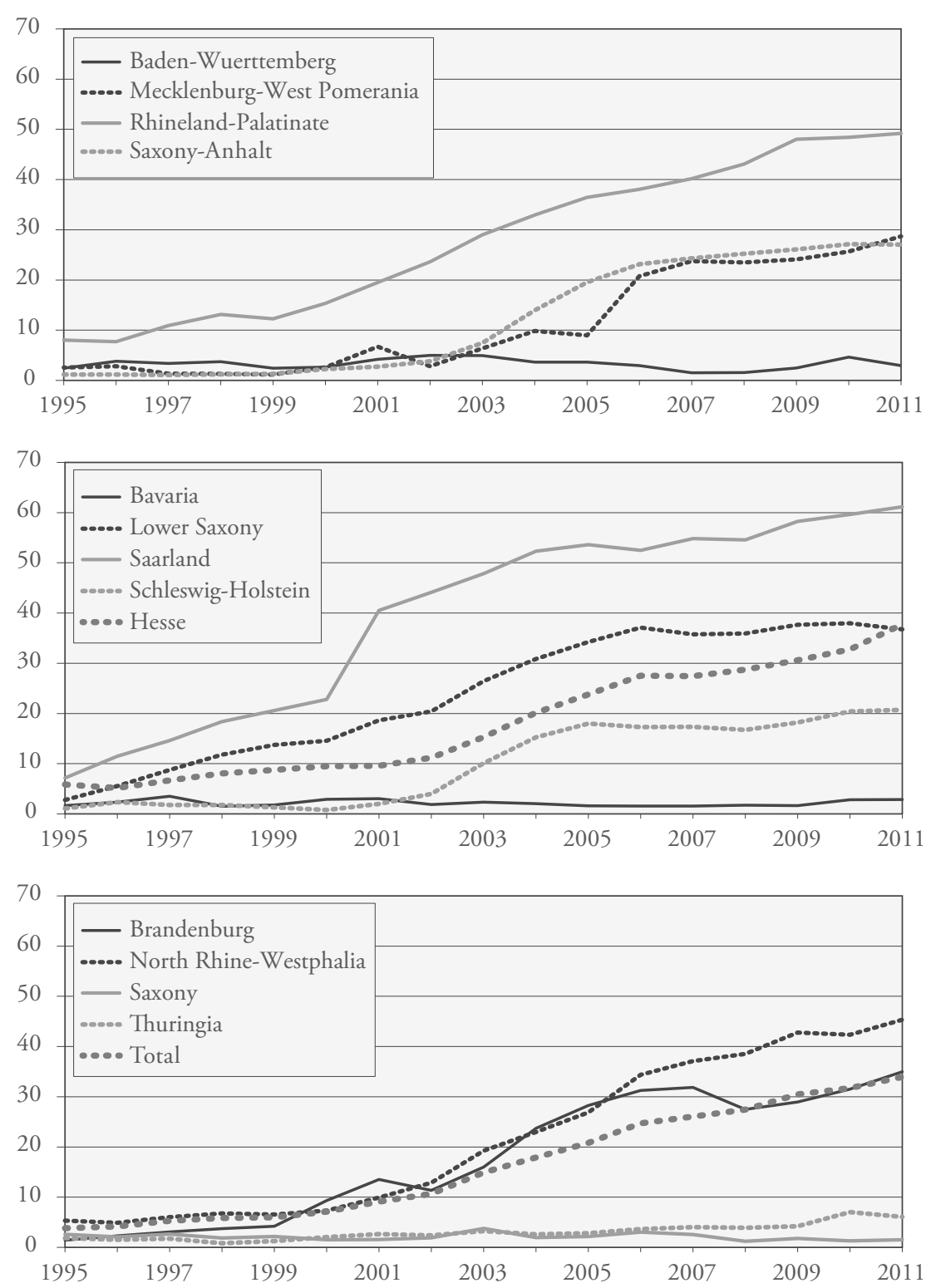

Note: In 2010 the definition of total municipal debt has changed subtly.

Source: Statistisches Bundesamt. 
(2013) provide time series evidence rejecting the hypothesis of fiscal sustainability in Germany after the Second World War. Although the annual growth rate of GDP exceeded the annual interest rate in the years 2010-2012, a permanent move towards fiscal sustainability is not in sight. Instead this process primarily results from temporarily low interest rates due to the European debt crisis and dynamic economic growth in the aftermath of the financial crisis.

Figure 4: (Un)sustainability of German Fiscal Policy, 1970-2010 in \%

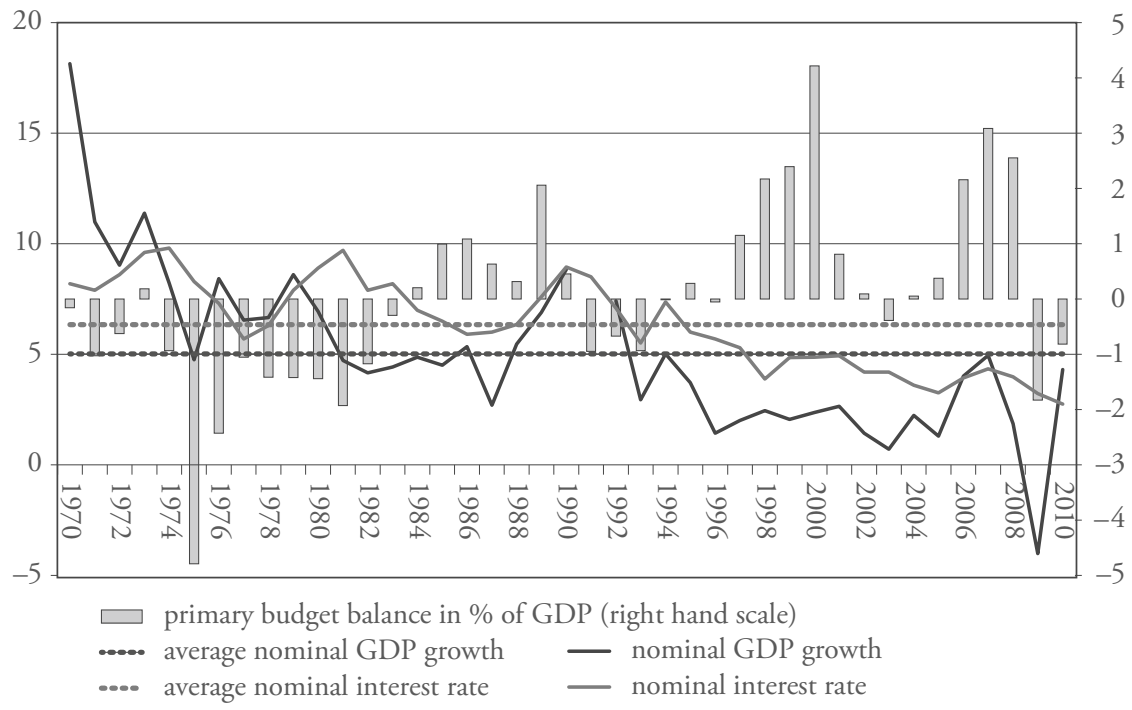

Note: Interest rate on ten-year government bonds.

Sources: Statistisches Bundesamt and IMF.

Fiscal consolidation in Germany is even more urgent when considering the demographic development: The changes in the structure and the size of the labour force is estimated to reduce the potential long-term growth to around 1\% (SACHVERSTÄNDIGENRAT 2011a) while the interest rate averaged out $4.5 \%$ since 2000 . As the interest rate will probably exceed GDP growth, the sustainability condition of Domar will only be met if primary surpluses are generated. In addition, the demographic development implies an increase in expenditures, especially in social security spending. Primary surpluses are, thus, even harder to obtain. Without any consolidation the debt ratio is projected to exceed 100\% in 2034 and 200\% 
twenty years later (Figure 5). Because an adjustment of social security contributions may curb public debt to only $107.7 \%$ by 2060 , it is not prevented from increasing. In addition to social security reforms further consolidation measures are thus inevitable for sustainable public finances in Germany.

Figure 5: Forecast of the General Debt Ratio until 2060, in \% of GDP

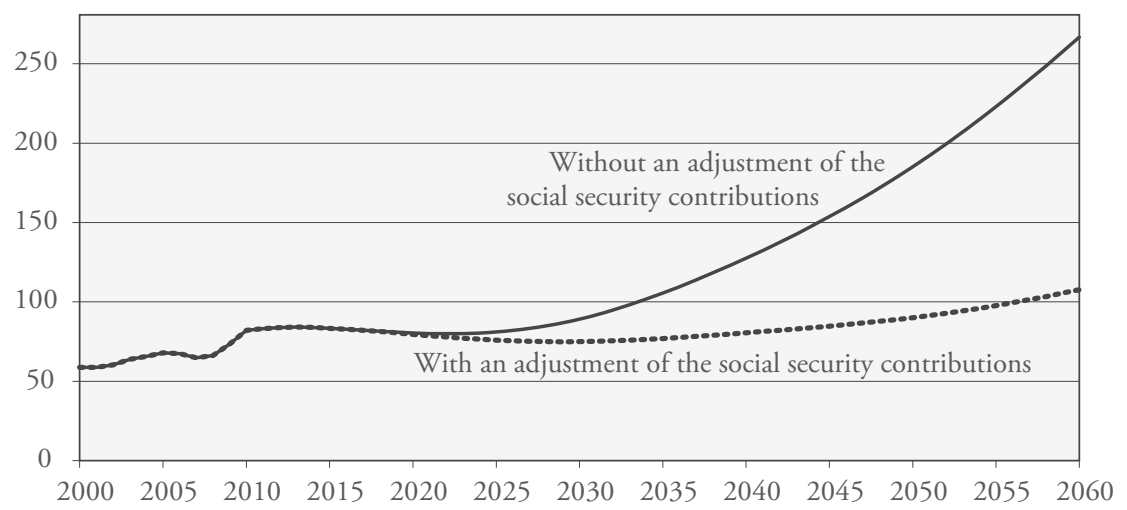

Note: A consolidation of 3.2\% is assumed for the period 2011-2015.

Source: SACHVERSTÄNDIGENRAT (2011a).

\section{Determinants of Public Debt}

In order to successfully restrain a further rise in public debt, the driving forces of fiscal deficits need to be considered. The impact of economic and socio-demographic determinants on public debt is widely accepted. Economic downturns put a burden on public finances as automatic stabilizers imply a reduction of tax revenue and an increase in social spending. While most economists acknowledge that automatic stabilizers should be allowed to work, the effectiveness of further discretionary fiscal policy is controversial since the multiplier effect of such measures is not unambiguous. ${ }^{2}$ Yet, the fiscal effects of automatic stabilizers should be more or less neutral across economic cycles and can, thus, neither explain the steady increase in public debt nor the missing consolidation in economic upturns.

2 Empirical evidence for Germany suggests rather small effects (Roos, 2007), but there is a continuing debate (see, e.g., Cwik and Wieland, 2011). 
Supplementary determinants of public debt are constituted by exogenous largescale events like natural disasters, wars or other extraordinary situations. Immediate tax adjustments in order to cover the necessary expenditures implied by such events are hardly appropriate. Instead, welfare gains might be realized by smoothing distortionary taxation over time through public borrowing (BARRO 1979). Yet, as it is the case with automatic stabilizers, tax smoothing implies debt to be eventually paid. Hence, tax smoothing can hardly be held accountable for increasing debt levels.

The effects of economic turmoil (shaded areas) and large-scale events, like the two World Wars and Reunification, on public finances in Germany are illustrated by Figure 1. Obviously, these temporary influences explain the development of German public debt only insufficiently. This holds in particular with respect to the missing consolidation in economic upturns. A similar lack of explanation is observed by MıкоsCH and ÜBeLMESSER (2007) regarding the variation of public debt ratios in OECD countries.

The missing link explaining a continuing debt growth (even in cyclical upturns) is provided by political economics. According to this theory, politicians act as self-interested, rational individuals restricted by formal and informal rules. The best way for a politician to gain an increase in income, political power and prestige or to serve their constituencies or to realize their individual ideological goals is to get (re)elected. Politicians thus face incentives to increase spending and decrease taxes, resulting in deficits. The rationale behind this strategy was stated by Buchanan (1986/2000: 454): "Constituents enjoy the benefits of public spending; they do not enjoy taxes."

The theory of the fiscal commons can be traced back to Tullock (1959) and Buchanan and Tullock (1962, chapter 10 and 11) (see Schaltegger and FELD, 2009). It is essential for understanding the mechanisms leading to excessive public spending and excessive public debt. Government finances can be seen as a common pool accessible to various interest groups. While the benefits of targeted public spending are concentrated on those privileged groups that obtain public funds, the costs are widely spread across taxpayers today and - through debt - into the future. Since the favoured groups do not face the full costs of the public benefits obtained, their demand for public services increases up to the point when their marginal benefits from public funds equals their marginal costs of tax financing. The additional burden of the extra spending is shared over a broad group of individuals, such that the privileged groups exert an excessive demand for government spending. Public finances get eventually overused and government debt accrues. In addition, taxpayers may be subject to fiscal illusion such that - contrary to classical concepts of RICARDo (1821) and BARRO 
(1974) - citizens' perceptions are systematically biased towards an underestimation of the necessary future rise in taxes due to fiscal deficits today. Analogously, the problem of the fiscal commons may also reduce the prospects of a successful consolidation. Since each interest group, politician and bureaucrat tries to prevent spending cuts and tax hikes in the area of interest, a broad consolidation is rather difficult to achieve (Alesina and Drazen, 1991).

Related to the problem of the fiscal commons is the issue of strategic debt use (Persson and Svensson, 1989; Tabellini and Alesina, 1990; Alesina and TABELLini, 1990). If a running party faces low chances of winning the next election, it has incentives to lower the fiscal and political leeway of subsequent governments by running high deficits. As borrowing burdens the next government, the currently ruling party hopes to increase its chances for the next but one election. A review of empirical and theoretical literature on the various political mechanisms leading to a growth in public expenditures, deficits and debt is provided by FeLD (2011).

The problem of the fiscal commons might be particularly severe in federal states, depending on their fiscal framework. Notably three institutions could curb incentives for sound fiscal policies on the sub-federal level: First, a low level of sub-federal tax autonomy increases the likelihood of fiscal deficits as it implies a dependency on revenues from fiscal transfers and joint taxes. Since revenues from those sources can hardly be increased autonomously, the capability of sub-federal governments to react to unforeseen revenue shortfalls is limited to borrowing and spending cuts. Public deficits more likely accrue if the federal level mandates the provision of certain public services and, thus, requires a minimum spending at the sub-federal levels. In addition, a low political and fiscal autonomy reduces fiscal competition between the jurisdictions. Such a framework decreases citizens' capabilities to evaluate the benefits and costs of local policy measures through a comparison of tax-service-packages in different jurisdictions. Hence, the political incentives to service special interest groups, which are central to the problem of fiscal commons, are enhanced and taxpayers' sovereignty is mitigated.

A second federal institution, the revenue-sharing and fiscal equalization system, exacerbates the bias towards public debt arising from insufficient fiscal autonomy at the sub-federal levels. The more egalitarian revenue-sharing and fiscal equalization systems, the higher are the incentives for unsustainable state and local finances. If the fiscal equalization system levels out initial fiscal differences between jurisdictions, it becomes unattractive for sub-federal governments to generate own public revenue. Instead of (politically) costly tax collection whose revenue is, at least partly, redistributed through fiscal equalization, 
the funding through transfers and debt is politically more attractive. In addition, high public debt probably enhances the bargaining position of a jurisdiction regarding reforms of the transfer mechanism such that highly indebted jurisdictions obtain higher transfers from the equalization scheme. While the benefits of incurring debt are then locally concentrated the costs might be spread across all taxpayers through the fiscal equalization system.

A third federal institution further erodes the incentives for fiscal prudence: The implementation of joint liability for government debt enables jurisdictions to spread their debt burden across all entities, while keeping the benefits of subnational borrowing mostly within the jurisdiction. In addition, creditors are less worrisome, knowing that a financial bailout is likely to prevent a sub-federal default. Subsequently, excessive borrowing is less restricted by market forces through higher risk premiums. While the problem of the fiscal commons might generally be limited through fiscal rules, the federal institutions of limited tax autonomy on the sub-national level, a bailout rule and an egalitarian equalization scheme do not provide incentives for sound public finances in federations.

\section{Fiscal Rules: The Case of Germany}

As mentioned in the introduction debt restrictions have been in place at least since the formation of the German Empire. Aside debt restructuring events, nominal public debt in Germany has hardly ever declined during the last 160 years. It is, thus, likely that escape clauses in the fiscal rules have been exploited illustrating their inherent dilemma: A per se prohibition of public debt is not credible since the working of automatic stabilizers or spending due to extraordinary circumstances would imply immediate, and probably extensive, tax adjustments in order to still obtain a balanced budget by the end of the year. Thus, credible fiscal rules require legal exceptions for extraordinary situations and, at best, for automatic stabilizers to work. Exploiting such a flexibility of the escape clauses is however tempting for politicians. Such incentives to circumvent fiscal rules, e.g. through an "unjustified" use of escape clauses, might be mitigated through a certain design of the rules and supporting institutions: The cases of exceptional circumstances should be narrowly defined, limited to the most necessary ones, tied to repayment rules and require a qualified majority in both chambers of parliament. Further, mostly all financial transactions and the total government sector should be included. In order to strengthen the incentives to comply with the fiscal rules, the sub-national jurisdictions should be granted fiscal responsibility and extensive fiscal autonomy. 
The increase in German public debt, despite national and international deficit restrictions might, at least partly, be explained by the insufficient design of those rules and a lack of sub-national fiscal responsibility and autonomy. While the restriction of public borrowing to extraordinary needs and to public investment according to the first version of Article 115 of the German Basic Law (Grundgesetz) in 1949 seemed to work relatively well (see Figure 1), anecdotal evidence on nominal public debt suggests otherwise. Rather the extraordinarily high rates of economic growth during the 1950s and 1960s, known as the "economic miracle", kept the debt-to-GDP ratio relatively low. Nominal public debt instead increased by over $500 \%$ until 1970 . By taking nominal debt growth into account, it seems likely that the exception for investment related spending was interpreted loosely. A missing definition of public investments made this possibility political feasible (Burret, 2013).

In 1969 a revision of Article 115 Grundgesetz enabled the government to actively use countercyclical fiscal policy. The new rule allowed for deviations from the investment cap in the case of a disturbance of the general macroeconomic equilibrium ("Störung des gesamtwirtschaftlichen Gleichgewichts"). Besides the persisting shortcoming of a missing definition of the term investment, the existence of a disturbance and the corresponding credit volume was not unambiguously identifiable. This holds despite the rulings of the German Constitutional Court on April 18, 1989 and on July 9, 2007 requiring the government to spell out clearly the existence of a macro-economic disequilibrium and to show that the additional government debt is suitable for correcting the disequilibrium (BVerfGE 79, 311; 119, 96). In fact, the assessment of a disturbance remained within the responsibility of the government, a qualified majority was not necessary. The proof that certain policy measures corrected a macroeconomic disequilibrium has not been satisfyingly provided. Worse, special public funds ("Sondervermögen") were explicitly excluded from the deficit limit. The wide escape clauses and their loose definitions rendered a compliance with the debt restriction possible without keeping public indebtedness limited. Once deficits accrued a consolidation was not required, neither in 1969 nor before. Apparently, public debt increased excessively in the decades following the constitutional amendment of 1969 (Figure 1).

The Stability and Growth Pact (SGP), enacted in 1997, restricts public deficits to $3 \%$ and public debt to $60 \%$ of GDP. Deviations from these limits are allowed in extraordinary circumstances, too. Due to political pressure of Germany and France the SGP was weakened in 2005, especially with respect to the escape clauses. Since then the criteria have been contravened widely. Yet, the Council of Ministers (ECOFIN) has never approved any sanctions. Obviously the national finance ministers, which constitute ECOFIN, face incentives not to fine each 
other. The SGP could, thus, not prevent the excessive indebtedness of European member states. In December 2011 a reform came into force, introducing a restriction of the structural deficit, the duty to reduce the debt-to-GDP ratios below $60 \%$ and quasi-automatic sanctions in case of contraventions (see Section 6).

\section{The German Debt Brake in Light of German Fiscal Federalism}

The increase in public debt, the insufficient fiscal rules and the insight that not merely economic factors, but also political economics determine public deficits have led to the revision of Article 115 of the German Grundgesetz and the introduction of a (close-to) balanced budget rule, the German debt brake, in 2009. The Swiss debt brake served as a role model for its German counterpart despite the fact that its success has not been fully demonstrated. Empirical evidence suggests a deficit reducing effect of the Swiss cantonal debt brakes (FeLD and KIrChgässner, 2008), while the Swiss federal debt brake is still too young to be properly assessed. In addition, the success of the Swiss debt brakes should not be extrapolated to Germany since the design of the rule must be adapted to the quite different federal framework.

\subsection{Design $^{3}$}

The debt brake, as set out in Articles 115 and 109 of the German Grundgesetz and in the implementation law (Article 115-law), requires a structurally closeto-balanced budget. Starting in 2016 the federal deficit must not exceed $0.35 \%$ of GDP after cyclical adjustments. Hence, a structural deficit of about 10.4 billion Euros will still be allowed beyond 2015. ${ }^{4}$ The cyclical component broadens the deficit limit in economic downturns and requires surpluses in booms, allowing the automatic stabilizers to work symmetrically: Cyclically induced debts are legally forced to neutralize across time. Since cyclical deficits cannot be observed or measured directly, they are estimated using the output gap and the responsiveness of the public budget to this gap. The output gap is defined as the difference between GDP and the estimated potential output. The technical procedure determining the output gap coincides with the method used in the context of the Stability and Growth Pact (Deutsche Bundesbank, 2012b).

3 A detailed description of the German debt brake is provided by, e.g., Feld (2010), Feld and Baskaran (2010), Deutsche Bundesbank (2011), Federal Ministry of Finance (2012).

4 The amount is calculated with help of nominal GDP as estimated by the IMF. 
Public expenditures and revenues are further adjusted for financial transactions, which relate to financial assets and do not affect capital formation, e.g. privatization or loans. Credit authorization for special funds created after 2010 are not excluded anymore from the deficit restriction.

Besides cyclical borrowing an additional credit line may be provided by the majority of the members of the Bundestag in the case of natural disasters or other extraordinary situations that are beyond the government's control and significantly affect government finances. The use of these escape clauses requires an amortization plan which is designed to reduce the extra borrowing within a reasonable timeframe.

Unexpected deviations from the annual deficit threshold of $0.35 \%$ are recorded in a control account and are, thus, "kept in mind". Hence, the debt brake is binding when preparing and executing the budget (Federal Ministry of Finances, 2012). If the accumulated deficits in the control account surpass $1 \%$ of nominal GDP the allowed deficit of the next year is cut by the exceeding amount. Yet, the annual reduction is limited to at most $0.35 \%$ of GDP and takes only place in years with a positive change in the output gap, i.e. during economic upturns.

In line with Article 109 of the German Grundgesetz the states face similar rules starting in 2020. While the German Grundgesetz entirely prohibits structural deficits on the sub-national level, the precise drafting of the debt brake is in the responsibility of the states. For instance, the escape clauses are already given by the German Basic Law, however the states may lay down own rules regarding the required approval in the parliament and the amortization plan. Similarly, the legal form of the control account and the adjustments for financial transactions is left to the states. Cyclical adjustments of the fiscal deficit are only allowed in case of a symmetric treatment of the cyclical influences. If a state fails to legally implement the requirements of the debt brake until 2020, its constitutional rules will be overruled by Article 109 Grundgesetz which immediately bans public borrowing without any exception.

A transition period is currently in place until the debt brakes come into force in 2016 and 2020, respectively. Starting in 2011 the federal government has had to steadily reduce its structural deficit of the year 2010 to around 10 billion Euros, i.e., $0.35 \%$ of GDP, in 2016. So far the federal level has complied with these requirements; yet, this achievement rests on an overestimation of the starting value in 2010, unexpectedly strongly increasing public revenues in 2011 and 2012, and extremely low interest rates resulting from the Eurozone crisis.

During the transition period for the Laender until 2020, fiscal consolidation can hardly be enforced since the states enjoy budgetary autonomy. Only a newly established Stability Council, which is comprised by the federal ministers 
of finance and economics and the state finance ministers, may be able to unveil unsustainable developments in sub-federal and federal finances. In order to enable the five particularly highly indebted states, namely Berlin, Bremen, Saarland, Saxony-Anhalt and Schleswig-Holstein, to comply with the debt brake by 2019, consolidation assistances are paid. The annual volume of those transfers amounts to 800 million and is equally financed by the states and the federal level. These transfers can be ceased and reclaimed if the Stability Council states a violation of a state restructuring program. According to legal agreements the five states have to reduce their structural deficit of 2010 by a tenth each year starting in 2011. Although this is a challenging undertaking, it is not unlikely that the consolidation paths are satisfied, since the transitional assistance contributes a crucial amount to the states' revenues (Table 1). In 2011 all five states succeeded in reducing their structural deficits in line with their consolidation agreements. Yet, as with the federal level, the starting values, i.e. structural deficits of 2010, were overestimated since an increase in structural tax revenues was not taken into account, although this was already predictable.

Table 1: Consolidation Assistance and Structural Deficits in the Five Program States

\begin{tabular}{|c|c|c|c|c|c|}
\hline & Berlin & Bremen & Saarland & $\begin{array}{l}\text { Saxony- } \\
\text { Anhalt }\end{array}$ & $\begin{array}{c}\text { Schleswig- } \\
\text { Holstein }\end{array}$ \\
\hline Annual consolidation assistance & \multicolumn{5}{|c|}{$800 \mathrm{~m}$. Euros in total } \\
\hline $\begin{array}{l}\text { in million Euro } \\
\text { ( } \% \text { of total) }\end{array}$ & $\begin{array}{l}80 \\
(10 \%)\end{array}$ & $\begin{array}{l}300 \\
(37.5 \%)\end{array}$ & $\begin{array}{l}260 \\
(32.5 \%)\end{array}$ & $\begin{array}{l}80 \\
(10 \%)\end{array}$ & $\begin{array}{l}80 \\
(10 \%)\end{array}$ \\
\hline in Euro per capita* & 23.4 & 455.2 & 256.2 & 34.4 & 28.3 \\
\hline in $\%$ of own revenues $(2010)^{* *}$ & 12.4 & 279.6 & 244.6 & 58.4 & 20.9 \\
\hline in $\%$ of revenues $(2010)^{* * *}$ & 0.6 & 14.0 & 10.4 & 1.1 & 1.2 \\
\hline \multicolumn{6}{|l|}{ Structural deficit in 2010} \\
\hline in million Euro & 2011.5 & 1218.9 & 1247.5 & 767.2 & 1317.6 \\
\hline in Euro per capita* & 588.7 & 1849.6 & 1229.1 & 330.0 & 466.1 \\
\hline \multicolumn{6}{|l|}{ Annual structural deficit reduction } \\
\hline In million Euro & 201.2 & 121.9 & 124.8 & 76.7 & 131.8 \\
\hline in Euro per capita* & 58.9 & 185.0 & 122.9 & 33.0 & 46.6 \\
\hline
\end{tabular}

Note: ${ }^{*}$ Population in $2010 .{ }^{* *}$ Local state revenues without municipalities before revenue-sharing.

***Local state revenues without municipalities after revenue-sharing.

Sources: Konsolidierungshilfegesetz, Verwaltungsvereinbarungen zum Gesetz zur Gewährung von Konsoldierungshilfen and Statistisches Bundesamt. 


\subsection{Legal Loopholes}

The provisions of the German debt brake show crucial improvements compared to former deficit restrictions. Namely a (close-to) balanced budget amendment instead of the previous investment oriented restraint, the inclusion of newly created special funds, a more clearly defined cyclical adjustment of deficits, the ex ante and ex post application of the deficit limit and the narrowly defined exceptions. Yet, several flaws remain: ${ }^{5}$

1. The cyclical deficits are likely to be systematically overestimated (KempKes, 2012). Since neither an ex post test of potential biases nor a corrective mechanism is installed, the calculated surpluses and deficits need not neutralize over time, but public debt might build up. Further, revisions of the estimated output gap are often immense: The OECD estimate for the German output gap in 2009 was revised from $0.5 \%$ (spring 2008) of the potential output to $-5.4 \%$ (spring 2009) to $-3.5 \%$ (autumn 2009) and finally to $-4.5 \%$ (autumn 2011). For 2007 the estimates varied between $0.0 \%$ and $2.6 \%$ of the potential output (ibid.). Since (unforeseen) deficits due to differences between the estimated and the actual output gap enter the control account, it might be overburdened across time (SACHVERSTÄNDIGENRAT, 2010).

2. A high public debt in the control account is even more likely to accrue since no precise time frame is set, in which debt must be amortized.

3. Since the debt brake does not encompass the whole public sector, political incentives exist to shift expenditures and deficits toward those institutions not (fully) covered by the debt brake. First, financial transactions of granting and repaying loans are factored out although loan redemption and default obviously entail different fiscal effects. Second, in Private-Public-Partnerships a government authority pays charges to a private party for funding and running a certain service. While the public payments include the costs for servicing debt, the costs of borrowing do not enter the public balance sheet. Third, special public funds created before 2011 are not covered by the debt brake. It might even be feasible to assign new tasks to those off-budget funds (FeLD, 2010). Fourth, legally independent public companies, in particular at the local level, and the social security system are not included in the debt brake.

5 The Swiss debt brake in comparison offers hardly any of those loopholes: The control account has to be balanced within six years if the accumulated deficit exceeds six percent of previous years' spending. Exceptions from the deficit rule must be approved by both chambers, the Ständerat and the Nationalrat. Deficits due to escape clauses enter on the amortization account and are tied to repayment schedules. 
4. The consent requirement for the entitlement to use an exception from the deficit limit is relatively low. In fact, a simple majority of all members of parliament is already sufficient. This is called a qualified majority because all parliamentarians must be present, but it is far from two thirds majorities or the like. An approval of the second chamber of parliament is not necessary. In addition, a precise definition of an extraordinary situation and a specific time limit for an amortization is not provided.

5. The Stability Council has hardly the ability to impose sanctions or to intervene in case of unsustainable budget developments. Only the consolidation assistance payments to five Laender can be ceased and reclaimed in the year the state violates its consolidation agreement. However, this procedure does not apply automatically: The members of the Council, i.e., the national and Laender finance ministers, have to vote on a fine or the presence of exceptional circumstances. This framework of the Council corresponds to the flaws of the SGP. Further, the assessment criteria might not be successful in their aim to unveil unsustainable developments of public finances in time (Deutsche Bundesbank, 2011).

6. Since the balanced budget amendment of Article 109 III Grundgesetz refers only to the federal and Laender budgets, new off-budget activities do not seem to be completely out of question (Deutsche Bundesbank, 2012a). Depending on the interpretation of the wording of Article 143 Id GG it could be argued that new public funds are merely prohibited on the federal level, offering the states a wide loophole.

7. The transition period and the structure of German fiscal federalism place incentives on sub-national governments to delay a necessary consolidation and accrue further deficits (Section 5.3 and 5.4).

\subsection{Implementation into Sub-National Law}

The implementation of the debt brake (as of January 2013) is far less advanced in the Laender as compared to the federal level. ${ }^{6}$ The Laender were granted a relatively long adjustment period phasing out in 2020. This circumstance owes at least partly to high consolidation requirements in some jurisdictions, which amount to up to 20 percent of their primary spending (cumulated from 2011 to 2019) in financially weak states (SACHVERSTÄNDIGENRAT, 2011b), and the overestimation of the fiscal burden due to the financial crisis in 2008/09 (Deutsche Bundesbank,

6 On the contrary, Swiss cantons had debt brakes in place long before it was introduced on the federal level. 
2012a). Not only the relatively highly indebted states, but most of all states seem to take full advantage of the transition period. In fact, precise amortization steps in terms of a structural deficit reduction until 2020 are only statutory in the five states receiving consolidation assistance and in Baden-Wuerttemberg, Hamburg, Lower Saxony and Rhineland-Palatinate. However, escape clauses enacted in these consolidation paths might delay a deficit reduction. In addition, a balanced budget is not mandatory before 2020 in most states (Table 2).

Besides postponing the necessary reduction of structural deficits, seven states have not even succeeded in implementing the new requirements of the debt brake into their ordinary or constitutional law. In these states the former debt restriction following the investment-oriented approach with the loosely specified escape clauses still applies. In fact, only five states have implemented the debt brake into their constitution and four states have reformed their Budgetary Regulation Law, i.e. Landeshaushaltsordnung (LHO).

\section{Implementation of the Debt Brake into Budgetary Regulation Laws (Table 2)}

The states of Baden-Wuerttemberg, Lower Saxony, Saxony-Anhalt and Thuringia have enshrined the debt brake into $\$ 18$ of their LHO. Yet, this step might not be sufficient in order to ensure a smooth working of the new fiscal rule. In fact, the LHOs could easily be circumvented or set aside for several reasons: First, an LHO can be amended by a simple majority in parliament, as every other ordinary law. Second, the Annual Budget Law overrides the LHO since it governs a more specific matter (lex specialis) and is later enacted (lex posterior). Third, the constitution enjoys a higher legal status than ordinary laws. Sub-national governments are, thus, enabled to invoke the escape clauses of the former debt restriction still anchored in their constitution. Recent evidence suggests a frequent use of these possibilities for circumventions: The lawmakers in Bavaria justified public borrowing for the recapitalization of the Bayerische Landesbank with an extraordinary need as still enacted in the Bavarian constitution, instead of using the escape clause enacted in $\$ 18$ LHO. Baden-Wuerttemberg used the loophole provided by the adjustment for financial transactions in 2009 and 2010. The government set up off-budget special purpose vehicles in order to grant financial support to its Landesbank and to repurchase shares of Energie Baden-Württemberg (Deutsche Bundesbank, 2011). Recently the government of BadenWuerttemberg removed the borrowing cap of its $\$ 18 \mathrm{LHO}$ with the result that the annual budget of 2012 complied with $\$ 18$ LHO. In fact, the reform of $\$ 18$ LHO was just a kind of "beauty treatment", due to lex specialis and lex posterior it is not deemed necessary. 


\begin{tabular}{|c|c|c|c|c|c|c|c|c|c|c|c|c|c|c|c|}
\hline \multirow{8}{*}{ 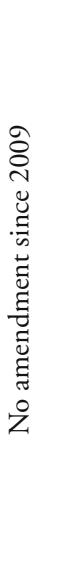 } & & & $\sim$ & $n$ & tr & $n$ & $\bullet$ & $\wedge$ & $\infty$ & $a$ & $a$ & $\stackrel{ }{ }$ & $=$ & & \multirow{21}{*}{ 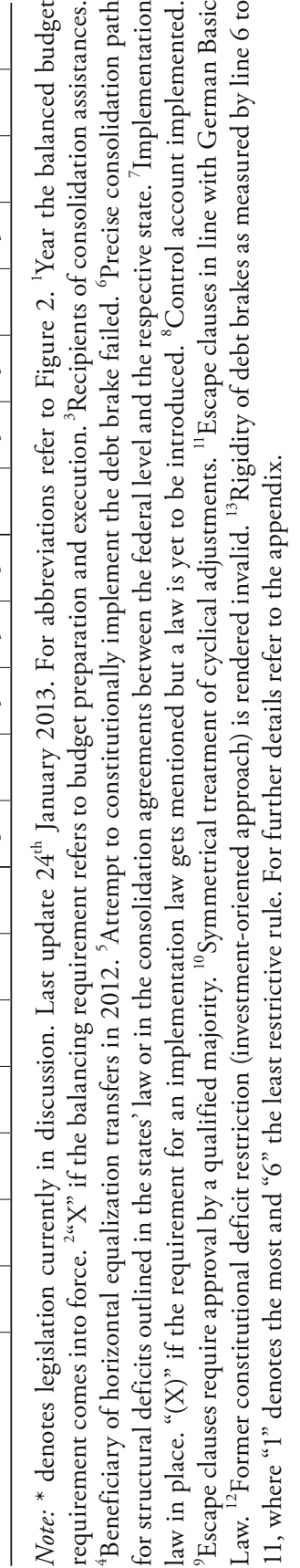 } \\
\hline & $\grave{x}$ & & & & 1 & ' & & 1 & 1 & & ' & ' & & & \\
\hline & $Z_{n}$ & oे & ' & 1 & $x$ & 1 & 1 & ' & ' & ' & I & 1 & & 6 & \\
\hline & $\vec{\omega}$ & 1 & 1 & $x$ & $x$ & ' & $x$ & ' & ' & ' & ' & ' & ' & & \\
\hline & Z & 1 & ' & 1 & $x$ & $x$ & ' & ' & ' & ' & ' & 1 & ' & ৩ & \\
\hline & 되 & ' & ' & $x$ & $x$ & $x$ & $x$ & 1 & 1 & ' & ' & 1 & ' & in & \\
\hline & & 1 & 1 & $x$ & $x$ & ' & $x$ & 1 & 1 & 1 & ' & 1 & ' & & \\
\hline & ב̂ & ' & ' & ' & $x$ & $x$ & 1 & 1 & 1 & 1 & I & 1 & 1 & 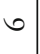 & \\
\hline \multirow{5}{*}{ 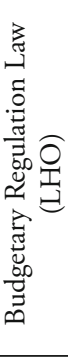 } & 不 & సి & $x$ & ' & ' & $x$ & $x$ & $\mathbb{Z}$ & $x$ & 1 & $x$ & $x$ & ' & $n$ & \\
\hline & $\bar{z}$ & $\approx$ & ' & ' & $x$ & $x$ & $x$ & 1 & ' & 1 & I & 1 & & $n$ & \\
\hline & $\stackrel{\mathbb{F}}{F}$ & $\Xi$ & & & $x$ & 1 & & 1 & 1 & & 1 & $x$ & & & \\
\hline & $\vec{n}$ & f & 1 & $x$ & $x$ & ' & $x$ & ' & 1 & 1 & $x$ & 1 & ' & $\checkmark$ & \\
\hline & $\frac{*}{\infty}$ & $\stackrel{\curvearrowright}{ }$ & $\rtimes$ & 1 & 1 & 1 & 1 & $\rtimes$ & $\Varangle$ & $\rtimes$ & $\rtimes$ & $\rtimes$ & 1 & $n$ & \\
\hline \multirow{8}{*}{ 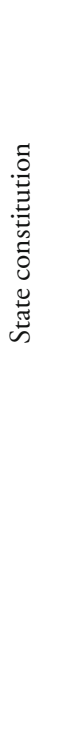 } & $\vec{\omega}$ & ㄱ & $x$ & $x$ & $x$ & $\stackrel{\pi}{a}$ & $x$ & $x$ & $x$ & $x$ & $x$ & $x$ & $x$ & - & \\
\hline & $\tilde{\simeq}$ & હે & $x$ & ' & $x$ & $\stackrel{\pi}{a}$ & $x$ & $x$ & $x$ & ' & $x$ & ' & $x$ & - & \\
\hline & $\sum$ & ㄱ & $x$ & ' & $x$ & $\stackrel{\pi}{\beth}$ & 1 & 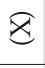 & ' & ' & $x$ & $x$ & $x$ & $N$ & \\
\hline & 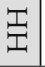 & 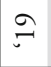 & $x$ & ' & $x$ & $\frac{\widetilde{a}}{a}$ & $x$ & 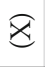 & ' & $x$ & $x$ & $x$ & $x$ & - & \\
\hline & 䛼 & ¿্ & $x$ & ' & ' & $\stackrel{\pi}{a}$ & & $\mathbb{Z}$ & 1 & ' & $x$ & $x$ & $x$ & $\sim$ & \\
\hline & $\stackrel{*}{*}$ & $\stackrel{\curvearrowright}{ }$ & ' & $\rtimes$ & $\rtimes$ & $\lesssim$ & $\rtimes$ & $\rtimes$ & 1 & $\rtimes$ & $x$ & 1 & $\rtimes$ & -1 & \\
\hline & $\frac{*}{\infty}$ & $\stackrel{\sim}{\sim}$ & $x$ & I & I & ミ & & $\nexists$ & ' & ' & $\Varangle$ & $\Varangle$ & $\Varangle$ & $v$ & \\
\hline & & 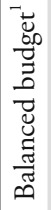 & 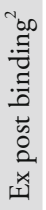 & 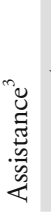 & 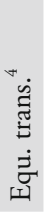 & 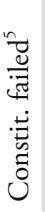 & 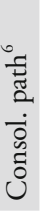 & 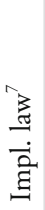 & 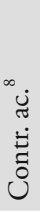 & 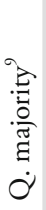 & 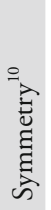 & 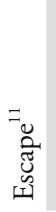 & 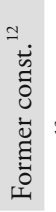 & $\begin{array}{l}\overbrace{x} \\
\stackrel{x}{0} \\
\vec{\Xi}\end{array}$ & \\
\hline
\end{tabular}

Swiss Journal of Economics and Statistics, 2013, Vol. 149 (2) 
In general, the debt brakes of the four states are less rigid compared to the debt brake of the federal level. For instance, the use of escape clauses requires no qualified majority in any of these states. Further, the need of an additional law governing the precise design and implementation of the sub-national debt brake, e.g., the control account, adjustments for the financial transactions and for the cyclical component, gets not even mentioned in any LHO but one. In the case of Lower Saxony fiscal deficits up to the amount of expenditures on investments and deviations in the case of macroeconomic disequilibrium are still allowed. Essential parts of the debt brake are, thus, not implemented. While the cyclical adjustment process can be manipulated easily in Thuringia, the debt brake of Saxony-Anhalt does not even specify any adjustment method. In fact, the symmetry requirement of the German Basic Law is only met by the debt brake of Baden-Wuerttemberg. Further, off-budget funds are not explicitly encompassed in any of the states' law. In all but one state the debt brake refers solely to budgetary preparation, but not to implementation. A new draft for an implementation of the debt brake into the Bavarian LHO is currently discussed in parliament. Since Bavaria has not amended its LHO or constitution yet, and the bill meets mostly all requirements of the German Basic Law, it is highly welcome.

\section{Implementation of the Debt Brake into the Constitutions (Table 2)}

The constitutional anchoring of debt brakes increases their effectiveness since an amendment requires a qualified majority. Invoking on escape clauses of the former fiscal rule is rendered impossible. So far, only five states have successfully enshrined the debt brake into their constitutions: Hamburg, Hesse, MecklenburgWest Pomerania, Rhineland-Palatinate and Schleswig-Holstein. In addition a constitutional implementation is currently discussed in Bremen and Bavaria. While the draft in Bavaria is supported by all parties in parliament but one, a referendum is mandatory. It is scheduled to take place in autumn 2013 (BAYERISCHER LANDTAG, 2012). Since the motion in Bremen is only put forward by the Social Democrats and the Green Party, the necessary two-thirds majority is questionable. Although introduced after 2009, the constitutional debt brakes are not necessarily in line with the requirements of the German Basic Law.

In most states invoking on escape clauses is not subject to a qualified majority in parliament. The provisions of Bremen and Rhineland-Palatinate even include new exceptional circumstances from the deficit limit. However, the additional escape clauses become invalid in 2020 since they will be overturned by the provisions of the German Basic Law. While off-budget funds and a precise reduction path for structural deficits are encompassed by the legal consolidation 
agreements, these legislations are only valid until 2020. In fact, consolidation steps and off-budget funds are solely incorporated into the constitution of Rhineland-Palatinate. An implementation law and a control account, securing compliance during budget execution, have yet only been enshrined in the legislation of Rhineland-Palatinate and Schleswig-Holstein. Their laws define the cyclical component basically as the difference between the "normal tax revenues" and the estimated tax revenues. While the exact calculation method is still to be specified in a legal decree (Rechtsverordnung), there might be enough leeway for governments to work towards an overestimation of the "normal tax revenues". In short, compared to the federal level the states' debt brakes seem less rigid. This holds if implemented into the LHO and, to a lesser extent, if enshrined into the constitutions. Hence, most loopholes mentioned in Section 5.2 are also valid for the sub-national level.

\subsection{Incentives on the Sub-national Level: Feast before the Fast}

States which have notable consolidation requirements, a missing consolidation path and a delay in the implementation of the debt brake (Table 2) risk an unbalanced budget in structural terms by 2020. Particularly, Brandenburg, Mecklenburg-West Pomerania, North Rhine-Westphalia, Rhineland-Palatinate and Thuringia might be on unsustainable paths. In fact, nominal public debt of most states increased in 2011 - despite historically strong revenues. ${ }^{7}$ In a nutshell, subnational governments might be tempted to "Feast before the Fast". Indeed, the framework of German fiscal federalism and the expiration of the Fiscal Equalization Scheme (FES) place incentives on sub-federal governments to accumulate public deficits, delay fiscal consolidation and take full advantage of the transition period until 2020.

\section{Incentives Arising from the Limited Tax Autonomy and the Implicit Joint Liability}

German fiscal federalism grants only little tax autonomy to the Laender. ${ }^{8}$ Thereby the states' capability to react to (unforeseen) budgetary changes is restricted on the revenue side to hardly any other means than borrowing. Since revenues can hardly be increased autonomously by the Laender, a jurisdiction with ailing

7 These encompass Baden-Wuerttemberg, Hesse, Lower Saxony, North Rhine-Westphalia, Rhineland-Palatinate, Saarland, Saxony-Anhalt, Schleswig-Holstein, Thuringia, Berlin and Bremen.

8 In 2011 the combined own tax revenues of the German states were below 2.3\% of the total tax revenues before revenues-sharing (Statistisches Bundesamt, 2012). 
finances by 2020 will demand higher fiscal transfers in order to comply with the debt brake. Hence, a delay in necessary consolidation measures might seem attractive to politicians.

This holds in particular since the risk that a state is forced to consolidate through spending cuts (or a default) is negligible: Back in the 1980s the highly indebted governments of Saarland and Bremen turned to the German Constitutional Court asking for a bailout. The two states claimed that coping with the fiscal burden themselves would imply large spending cuts which are hardly possible since most expenditures are determined by federal mandates and, if cut, it would threaten the constitutional requirement of equivalent living conditions throughout Germany ("Einheitlichkeit der Lebensverhältnisse im Bundesgebiet"). In 1992 the Constitutional Court finally ruled in favour of the two states. According to the judgment a bailout is required due to the principle of cooperation and support (Bündisches Prinzip) which the Court saw primarily materialized in the FES (BVerfGE 86, 148; SEITZ, 1999).' The ruling of the Constitutional Court exacerbated the common pool problem of German fiscal federalism: While the states are responsible for the accumulation of fiscal deficits, the costs of excessive indebtedness can be spread across all jurisdictions through the implicit joint liability.

\section{The German Fiscal Equalization System}

Besides the bailout rule and the limited tax autonomy, the incentives to accumulate deficits and postpone a consolidation are enhanced through the current structure and the expiration of the fiscal equalization scheme in 2019. Currently the highly egalitarian transfer system treats the most important (joint) tax revenues as a common pool. This pool gets redistributed among the 16 states and the federal level in five steps: The first stage, the vertical revenue sharing, distributes the value added tax (VAT), income and corporation tax among the different government layers. In a next phase revenue is horizontally allocated between the states. While the states' shares in the income and corporation taxes are basically determined by the principle of local revenues and $75 \%$ of the VAT revenues are assigned according to the states' population, the remaining share of VAT revenue gets supplementarily transferred to the fiscally weak states. In a third step horizontal fiscal equalization among the states takes place. States with the lowest financial capacity per capita, defined as the sum of a state's and its municipalities'

9 On the contrary, a lawsuit of Berlin was rejected by the Constitutional Court in 2006 pointing to Berlin being capable to solve its financial distress on its own. 
revenues per inhabitant, receive transfers from the relatively wealthier states. ${ }^{10}$ The more the financial capacity per capita exceeds the average value the higher are the transfer contributions of a state, and visa versa. After this stage the average fiscal strength of the financially weak new Laender rose to $94 \%$ of the total average in 2011 (Table 3). In a fourth step the federal government provides general vertical grants to states whose financial strength still remained below $99.5 \%$ of the average. A last stage distributes transfers to the East German states and Berlin in line with the provisions of the Solidarity Pact II.

This extensive transfer scheme almost levels out initial differences in the financial capacity of the 16 states. While the new Laender had a financial capacity per capita of around 53\% of the average after the first step of the revenuesharing (excluding VAT) in 2011, the share increased to $111 \%$ after all steps of the FES were conducted. The financial strength of the fiscally strong states decreased accordingly (Table 3). In fact, the per capita financial strength of the "poor" states as percentage of the average exceeded the strength of the former "rich" western non-city states when taking the full equalization process into account.

\section{Incentives Arising from the German FES}

Despite almost equalizing transfer payments, public debt was not less of an issue in the beneficiary states than in the contributors. In fact, the eastern states (including Berlin) received about 84.4 million Euros between 1995 and 2011 from the western states, especially due to contributions of Bavaria, Hesse, BadenWuerttemberg and Hamburg. However, nominal public debt increased during this period by $110 \%$ in the western states and by $95 \%$ in eastern states (including Berlin). ${ }^{11}$ Indeed, the fiscal equalization system provides incentives on governments to refrain from an increase in local revenues and incur debt instead.

A rise in the financial strength of a state - through, e.g., a tax rise, the attraction of companies or combating tax evasion and undeclared work - is hardly attractive to sub-federal governments since higher local revenues imply an increase (decrease) in the horizontal transfer payments (receipts). When taking the vertical, horizontal and municipal transfers into account the fiscal levelling implies a marginal rate of absorption above $100 \%$ in some states. That is, a one Euro increase

10 The population weight of the sparsely populated states of Brandenburg, Mecklenburg-West Pomerania and Saxony-Anhalt is slightly increased and the population of the city-states is weighted by $135 \%$.

11 The numbers include municipal debt and cash advances. 
Table 3: Financial Strength per capita in Federal States, in 2011*

\begin{tabular}{|c|c|c|c|c|c|}
\hline in $\%$ of the national average & 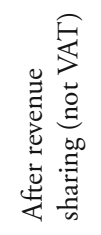 & 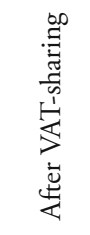 & 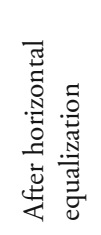 & 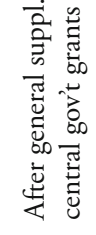 & 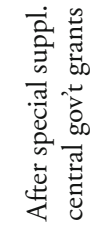 \\
\hline Bavaria & 127.9 & 112.0 & 102.6 & 101.5 & 97.8 \\
\hline Hesse & 124.5 & 112.2 & 102.6 & 101.6 & 97.9 \\
\hline Baden-Wuerttemberg & 118.3 & 106.3 & 101.0 & 99.9 & 96.3 \\
\hline North Rhine-Westphalia & 101.5 & 96.6 & 97.0 & 96.0 & 92.5 \\
\hline Rhineland-Palatinate & 96.6 & 93.8 & 95.7 & 95.7 & 92.6 \\
\hline Schleswig-Holstein & 95.5 & 94.8 & 96.2 & 95.8 & 93.0 \\
\hline Lower Saxony & 83.9 & 95.7 & 96.6 & 95.9 & 92.4 \\
\hline Saarland & 81.6 & 90.7 & 94.5 & 95.4 & 93.9 \\
\hline Western non-city states & 108.7 & 102.4 & 99.1 & 98.3 & 94.8 \\
\hline Hamburg & 155.6 & 133.9 & 132.8 & 131.5 & 126.7 \\
\hline Bremen & 96.5 & 95.0 & 120.3 & 127.2 & 125.4 \\
\hline Berlin & 85.5 & 91.0 & 119.4 & 127.0 & 136.4 \\
\hline City states & 107.9 & 104.4 & 123.5 & 128.4 & 132.2 \\
\hline Brandenburg & 62.4 & 88.7 & 94.4 & 95.9 & 109.7 \\
\hline Saxony-Anhalt & 51.6 & 85.9 & 93.5 & 95.5 & 112.0 \\
\hline Saxony & 51.4 & 86.0 & 93.2 & 95.1 & 109.9 \\
\hline Mecklenburg-West Pomerania & 50.9 & 85.1 & 93.6 & 96.0 & 112.0 \\
\hline Thuringia & 50.7 & 85.4 & 93.0 & 95.1 & 110.8 \\
\hline Eastern states & 53.4 & 86.3 & 93.5 & 95.4 & 110.7 \\
\hline
\end{tabular}

Note: ${ }^{*}$ Provisional figures only. For further details refer to source.

Source: Deutsche Bundesbank (2012a).

in local revenues reduces (raises) the receipts (contributions) by more than one Euro (Feld und Schnellenbach, 2013). The common pool problem becomes apparent: Politicians face hardly any incentives to increase their tax revenues, but to reap large transfer payments and to incur debts. Since public borrowing has 
hardly any effect on a state's fiscal equalization transfers, it is much more attractive to sub-national governments to generate revenues by means of debt than by increasing local revenues, which would get redistributed. ${ }^{12}$

\section{Incentives Arising from the Expiration of the German Fiscal Equalization System}

The German fiscal equalization system expires at the end of 2019. However, a restatement is deemed necessary due to the Bündisches Prinzip and the interjurisdictional differences in the financial power. The required reform of the fiscal equalization system might enhance sub-national incentives to accumulate fiscal deficits, particularly owing to three mechanisms:

1. As the realization of extensive sub-national tax autonomy is politically difficult, the inter-jurisdictional differences in financial power are likely to be met by fiscal transfers. In fact, the history of the fiscal equalization system teaches that the financially weaker a state by the time the negotiations take place, the better are the chances to receive a larger proportion of the transfer volume. Hence, sub-federal governments have incentives to postpone a necessary consolidation.

2. The bargaining power of the central government might weaken because it has to follow the legally fixed consolidation path and structural deficits are prohibited beyond 2016. On the contrary, the combined bargaining power of the states increases with the number of highly indebted states. This constellation could enable the states to reap a larger share of the joint taxes and place, thus, incentives to refrain from fiscal consolidation within the next years. Despite the sub-national debt brakes coming into force in 2020, sound public finances are still questionable. Since the fiscal rules allow for circumventions and have yet not been tested in the field, the highly indebted states might form a coalition and interpret the provisions of the debt brake loosely (Heinemann, 2012).

3. Indeed, also the states receiving consolidation assistance might refrain from further consolidation. In such a case the Stability Council, i.e. the state and federal ministers, has to decide on reclaiming the annual adjustment transfers. Since a reclaim might imply the need for larger (permanent) equalization payments to the respective state in the future, it seems likely that the ministers vote on an exceptional circumstance and omits a necessary reclaim.

12 In fact, Galmarini et al. (2007) provide empirical evidence for the US states suggesting that fiscal transfers do not merely lead to increased spending and decreased taxes (flypaper effect) but to a rise in public deficits. 
Hence, the five states receiving consolidation aid might also risk an unbalanced budget by 2020 .

\section{The European Fiscal Compact}

In 2012 mostly all Euro zone countries had ratified the Fiscal Compact ("Treaty on Stability, Coordination and Governance in the Economic and Monetary Union") and, thus, agreed to reduce their public deficits. This agreement is deemed to be respected if the structural deficit of the general government sector equals or is below the Medium Term Objective (MTO) of a country, which is limited to $0.5 \%$ of GDP. In case the debt-to-GDP ratio is significantly below $60 \%$, the upper limit of the MTO increases to $1 \%$ of GDP. Yet, the MTO's might be set closer to the upper boundary than actually necessary since they are autonomously determined by the national governments.

While the Fiscal Compact and the German debt brake specify similar escape clauses, five crucial differences can be stressed: First, the Fiscal Compact encompasses almost the whole government sector, e.g., special public funds, the social security systems, and special purpose associations. In a first benchmark paper on the inner-German implementation of the Compact, the states agreed to be held accountable for their communities, while the social security system is assigned to the federal level. Second, an implementation into national legislation has to be conducted by the end of 2013, thereby shortening the transition period granted by the German debt brake. Third, the contracting states have to reduce their debt-to-GDP ratios on average by $1 / 20$ per annum to $60 \%$ of GDP. ${ }^{13}$ Fourth, financial sanctions might be imposed if an implementation of the provisions of the Fiscal Compact is not successfully conducted by 2014 . However, a priori a contracting state has to bring the case before the European Court of Justice. Fifth, an independent institution, set up at the national level, should monitor the compliance with the rules. In case of a significant deviation from the MTO a corrective mechanism is required to be triggered automatically.

Further sanctions are provided by the reformed preventive arm of the renewed Stability and Growth Pact. If a qualified majority of the ECOFIN-Council declares a country in violation of its MTO, quasi-automatic sanctions in form of interest bearing deposits apply. Contrary to the former SGP the sanctions can

13 Germany and all other states subject to an excessive deficit procedure in November 2011 do not have to comply with this requirement before 2015 . 
only be blocked by a qualified majority in the Council. In the case a country does not conduct any corrective measures the deposit can be translated into a non-interest bearing fine in the amount $0.2 \%-0.5 \%$ of GDP later on. For Germany this could add up to 13.67 billion Euros in 2013 and 15.28 billion Euros in 2017, using nominal GDP estimates by the IMF.

In light of the earlier and broader consolidation requirements, the Laender approved the Fiscal Compact in the Bundesrat only after the central government provided fiscal concessions, e.g., funds for childcare places, to the states and municipalities (Deutsche Bundesbank, 2012a). However, a first draft of an implementation law was rejected by the states at the end of 2012 (BTDrs. 17/10976). A new one was proposed in mid-January 2013 (BT-Drs. 17/12058) and is still pending. Besides bringing the Budgetary Principles Act (Haushaltsgrundsätzegesetz) in line with the requirements of the Fiscal Compact and providing the committed funds to the sub-national governments through amendments in the Fiscal Equalization Law the current draft touches on several other issues: First the control account of the federal debt brake is to be set back to zero by the end of 2015. According to the government this should ensure that the account is not positive when the debt brake becomes effective in 2016. Since a negative balance of the control account is also to be deleted, a wider use of this account might appear tempting to politicians. Second, the responsibilities of the Stability Council are enhanced and an independent advisory board is supplemented. Despite monitoring the structural deficit of the general government and providing recommendations in case of contraventions against the MTO, neither the Council nor the advisory board has any possibility to impose sanctions. Third, the draft amends the distribution of potential EU-sanctions between the federal and sub-federal level. While the share of the central government amounts to $65 \%$, the states have to bear $35 \%$. The sub-federal share is further divided among the states according to the state's population $(35 \%)$ and to the state's share of total deficit (65\%). Yet, sanctions due to deviations from the MTO are solely paid by the federal level until 2020.

In light of the already existing incentives to delay a consolidation on the subnational level, the Fiscal Compact is not of much help. Since the sanctions are solely paid by the federal level until 2020, the sub-national incentives have hardly changed. However, beyond 2019 the threat of financial sanction might increase incentives to comply with the provisions of the Fiscal Compact. 


\section{Conclusions}

Public debt in Germany has become unsustainable in recent decades such that a consolidation of government finances is necessary. This development cannot be explained by (macro-) economic shocks or singular events like reunification though the initial impulse to incur public debt may stem from that. The continuing trend in increasing indebtedness rather reflects the inability of governments to consolidate budgets in good times. This lack of fiscal responsibility is due to political forces that induce a fiscal commons problem.

The new fiscal rules in Germany, i.e., the German debt brake, aim at correcting the resulting bias towards public debt. While the debt brake is an improvement as compared to the old version of Article 115 Grundgesetz, mainly because the investment orientation of public debt is dropped, new special funds are prohibited and the general allowance to incur debt in a macroeconomic disequilibrium has become specific, many loopholes remain that pose a danger for the effectiveness of the debt brake. Nevertheless, the federal government appears to be able to comply with the debt brake even earlier than the required year 2016.

The most important shortcoming of the German debt brake is its inability to effectively control debt at the state and local levels. The federal government does not have the powers to intervene into state budgets, but the Laender do also not have to fully bear responsibility towards their creditors due to an implicit joint liability in the German fiscal constitution. Key for a success of the debt brake thus is the compliance of the Laender. The litmus test for the new debt brake will be the willingness of the Laender to observe the constitutional limits on their government finances. 


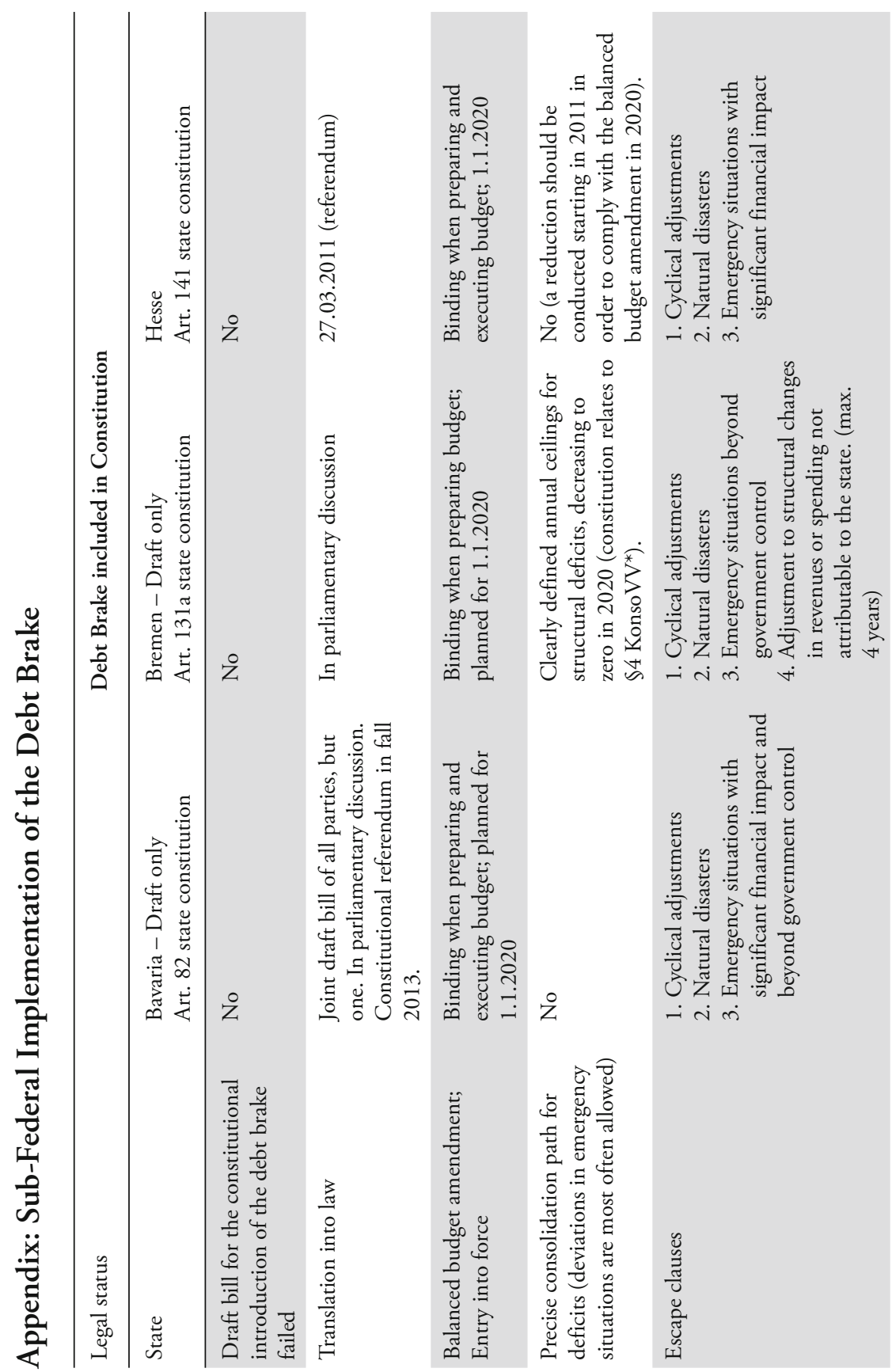

Swiss Journal of Economics and Statistics, 2013, Vol. 149 (2) 


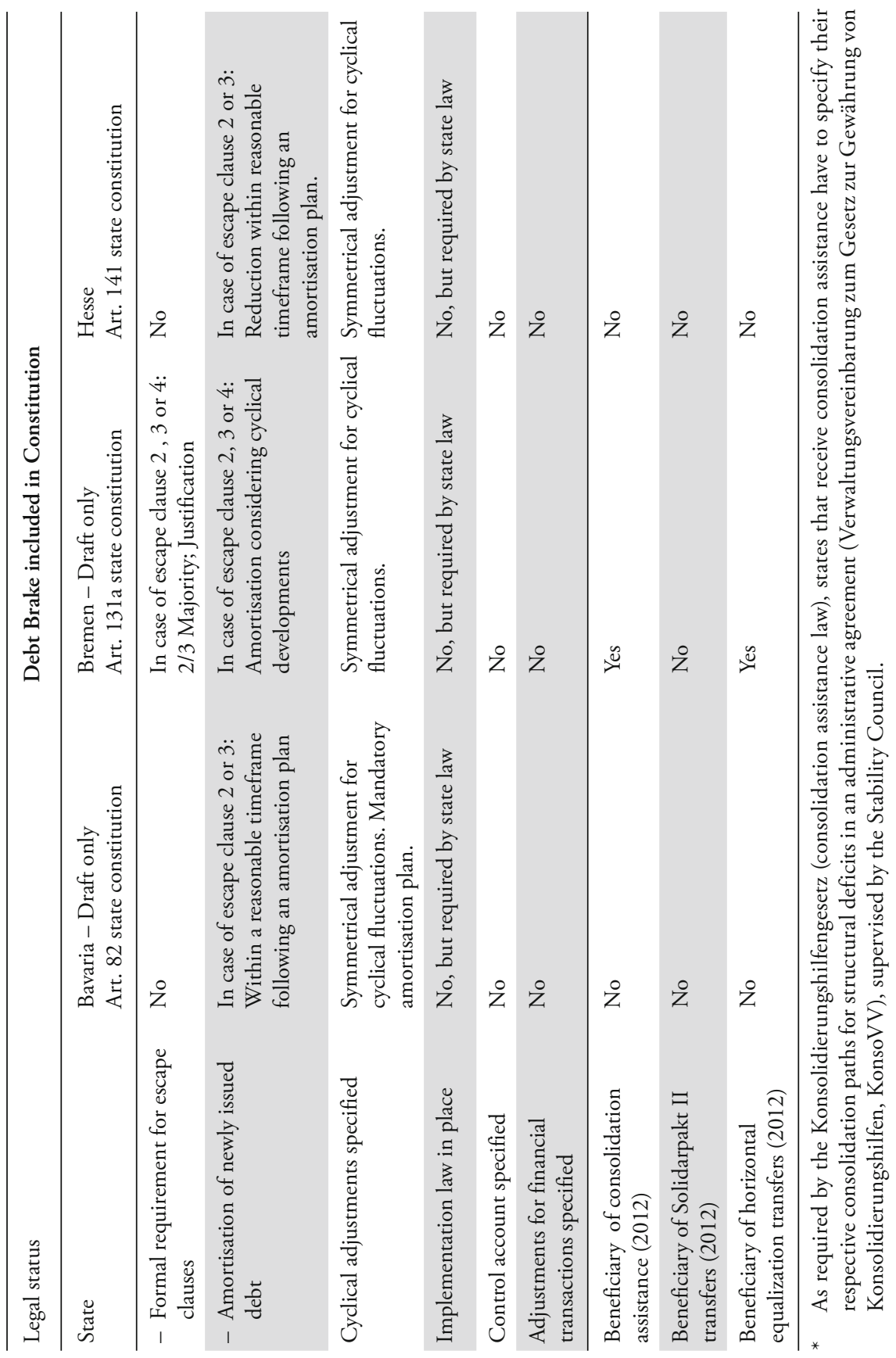

Swiss Journal of Economics and Statistics, 2013, Vol. 149 (2) 


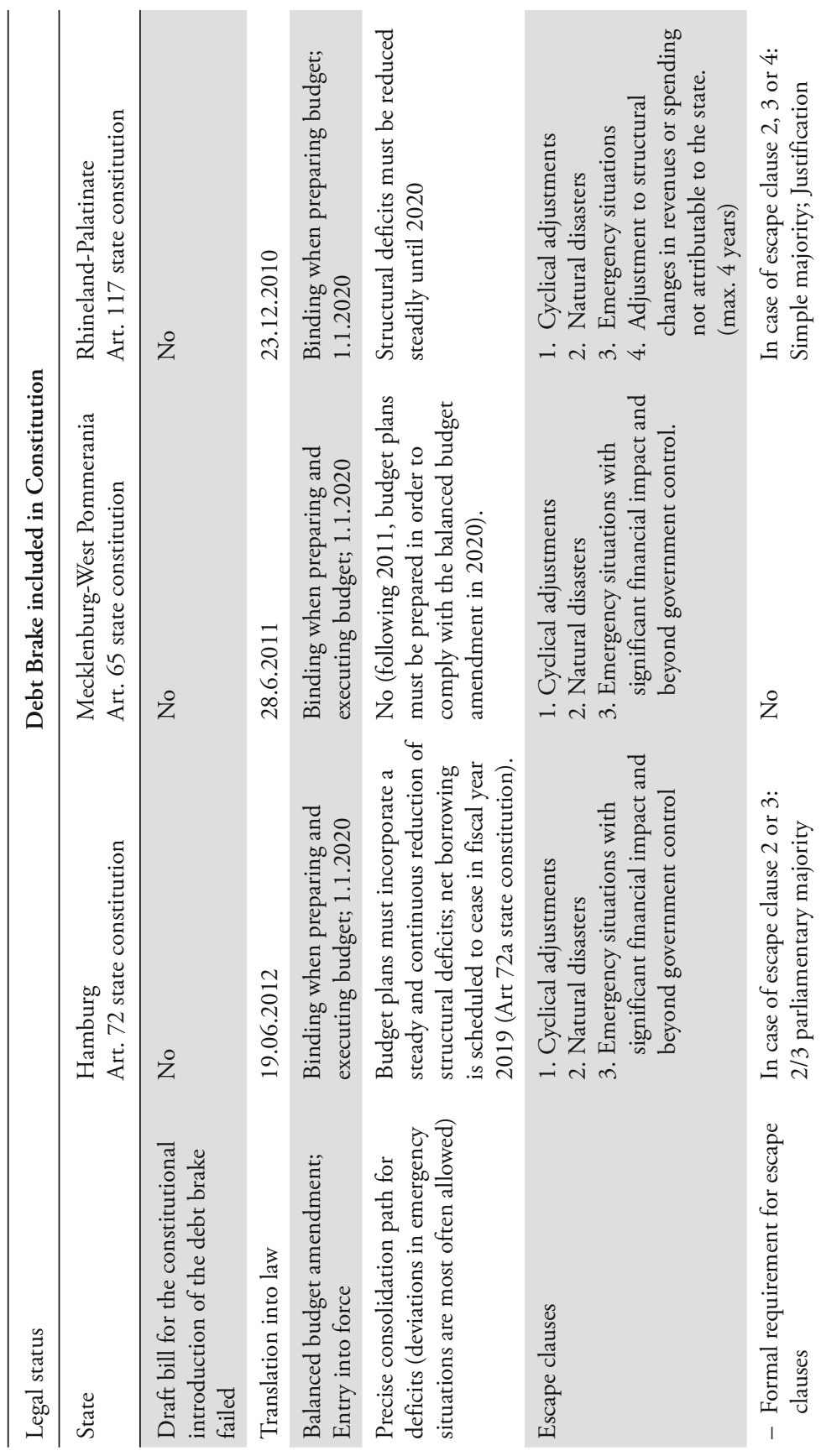




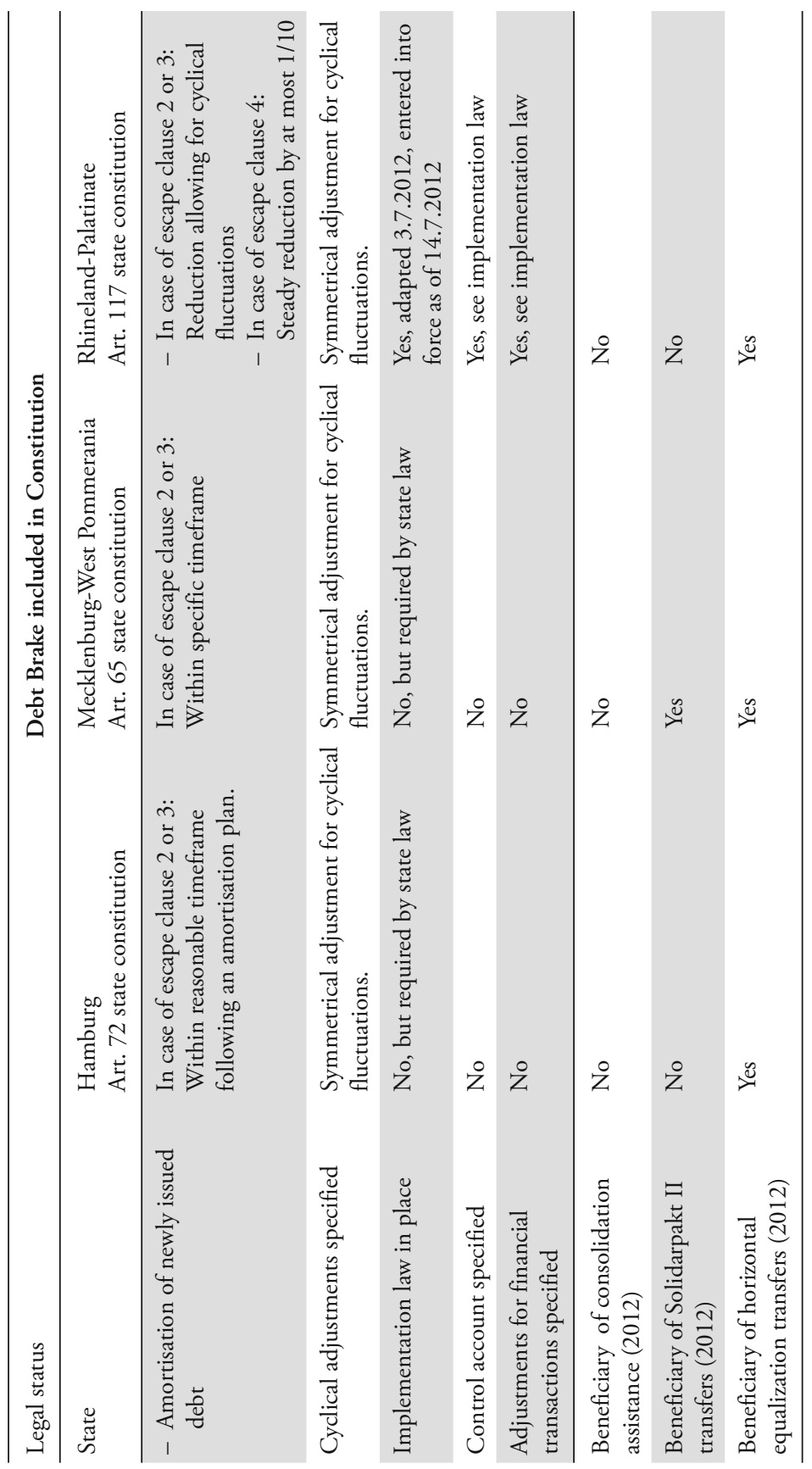




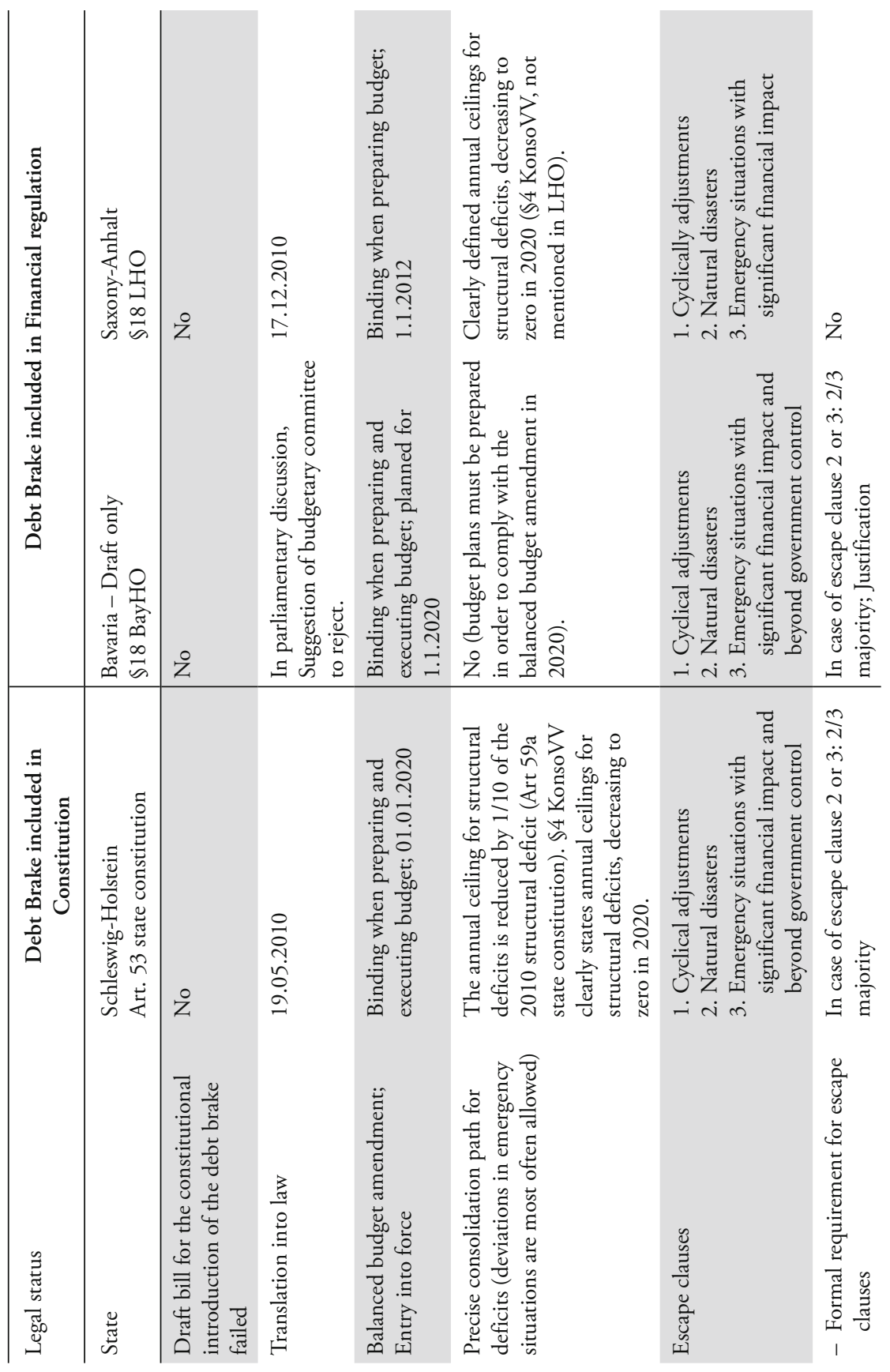

Swiss Journal of Economics and Statistics, 2013, Vol. 149 (2) 


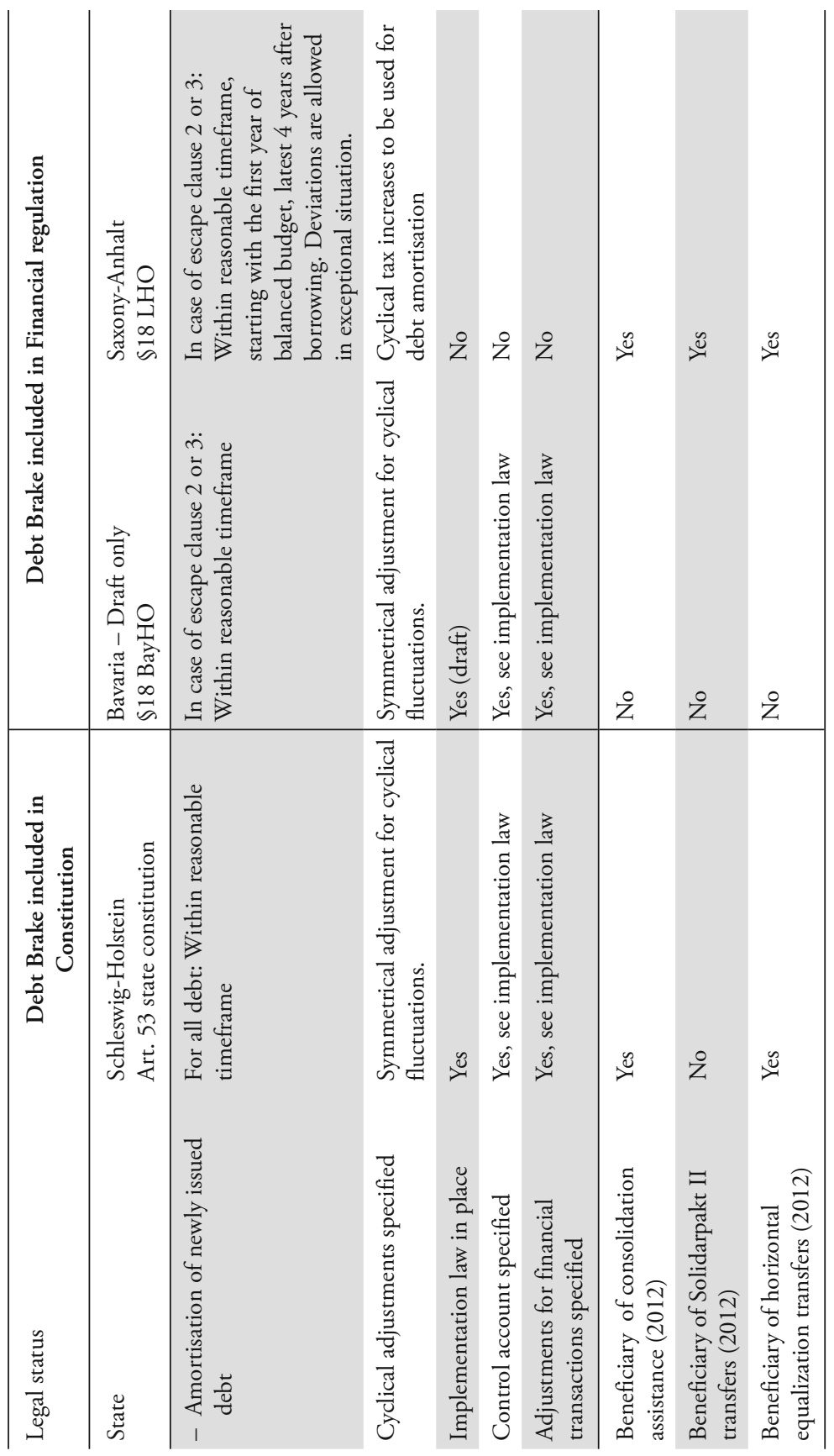




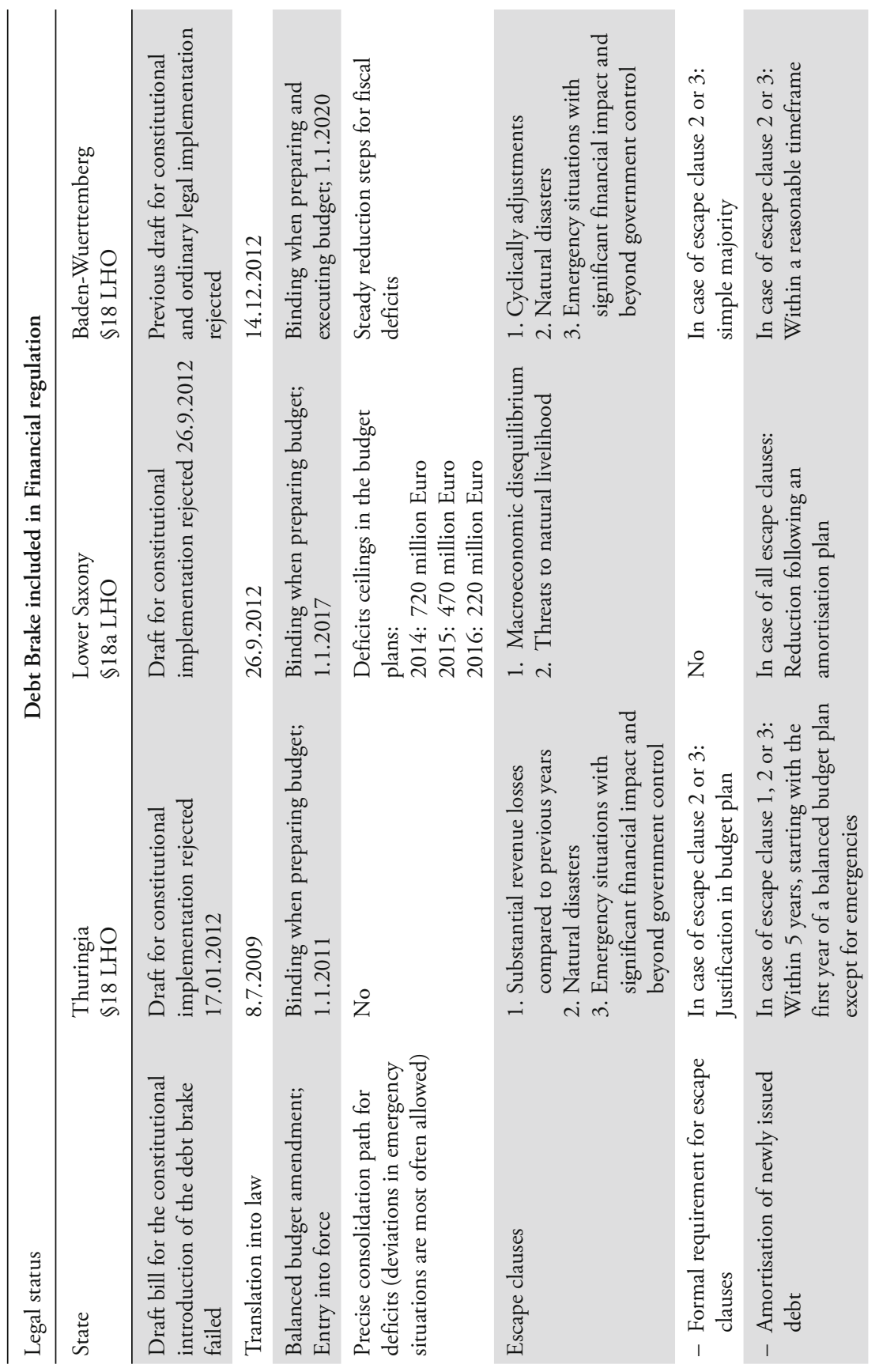




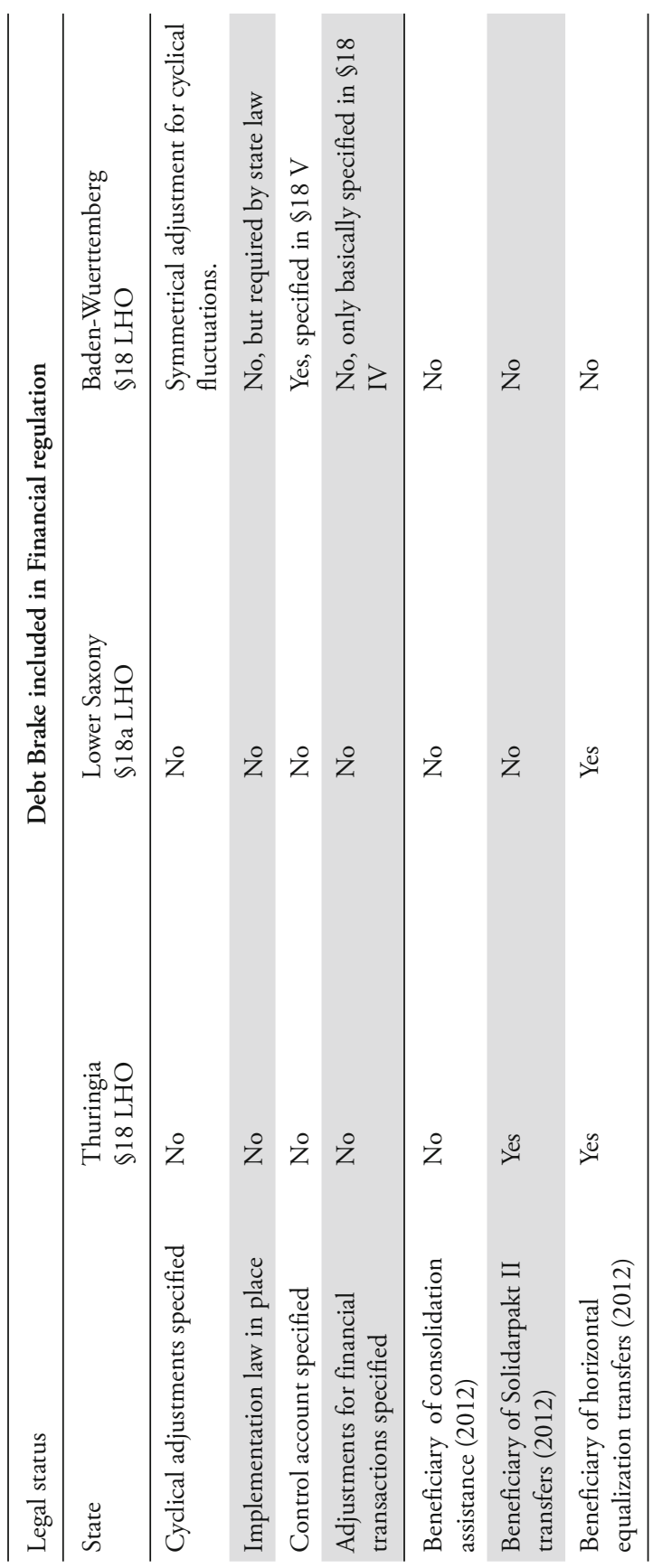




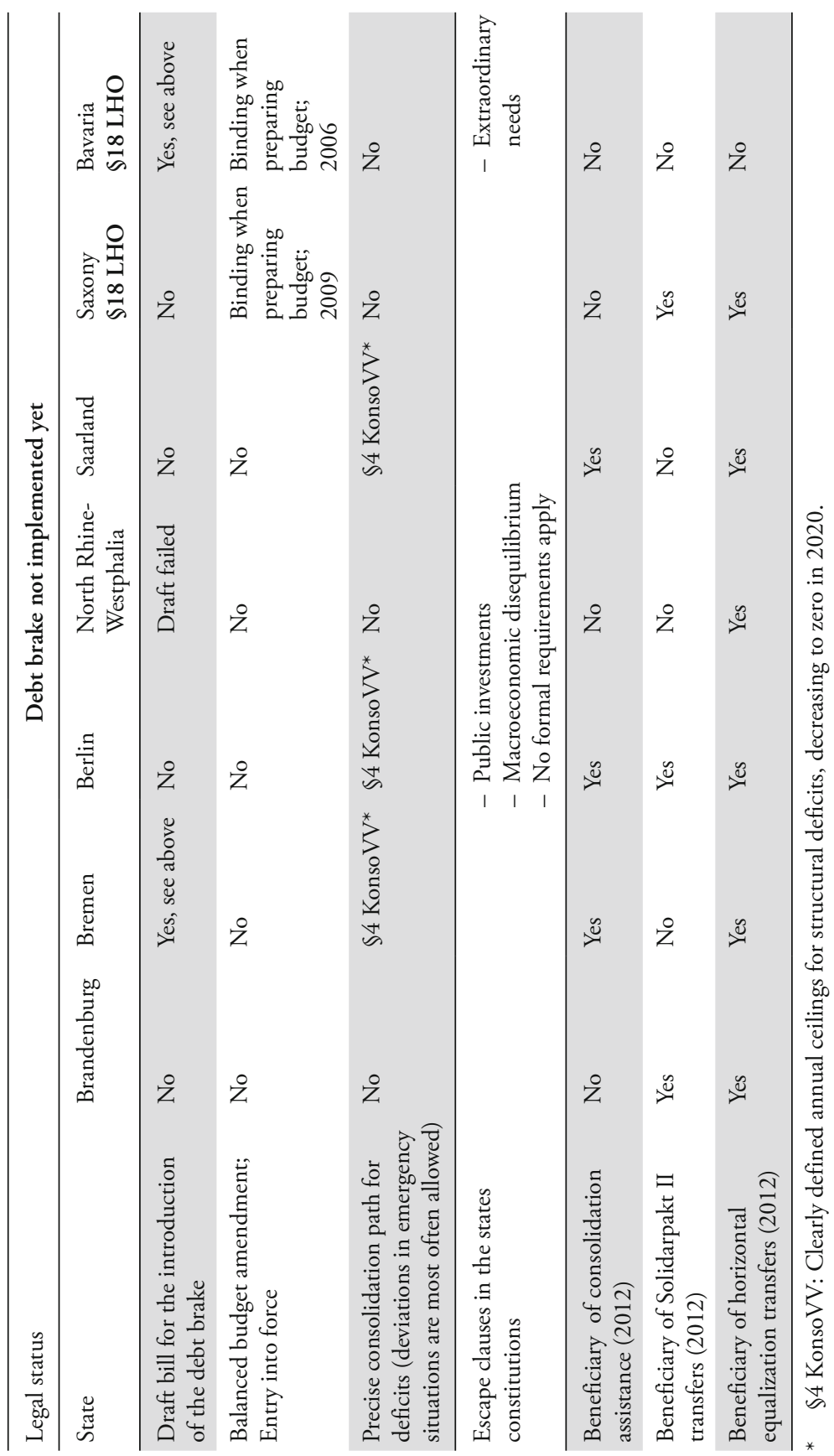

Swiss Journal of Economics and Statistics, 2013, Vol. 149 (2) 


\section{References}

Alesina, Alberto and Allan Drazen (1991), "Why Are Stabilizations Delayed?", American Economic Review, 81, pp. 1170-1188.

Alesina, Alberto and Guido Tabellini (1990), "A Positive Theory of Fiscal Deficits and Government Debt", Review of Economic Studies, 57, pp. 403-414. Barro, Robert J. (1974), "Are Government Bonds Net Wealth?”, Journal of Political Economy, 82, pp. 1095-1117.

Barro, Robert J. (1979), "On the Determination of the Public Debt", Journal of Political Economy, 87, pp.940-971.

BAYRISCher LANDTAG (2012), „Verfassungsänderung in fünf Punkten: Vier Fraktionen bringen Reform auf den Weg“, Pressemitteilung vom 12. December 2012.

Buchanan, James M. (1986/2000), "The Economic Consequences of the Deficit", in The Collected Works of James M. Buchanan: Debt and Taxes, Vol. 14, pp. 429-444, Indianapolis: Liberty Fund.

Buchanan, James M. and Gordon Tullock (1962), The Calculus of Consent. Logical Foundations of Constitutional Democracy, Ann Arbor: University of Michigan Press.

Burret, Heiko T. (2013), „Die deutsche Schuldenbremse als Panazee? - Eine Analyse im historischen Kontext", forthcoming in: Journal für Generationengerechtigkeit 2013 (2).

Burret, Heiko T., Lars P. Feld and Ekkehard A. Köhler (2013), "Sustainability of Public Debt in Germany - Historical Considerations and Time Series Evidence", forthcoming in: Jahrbücher für Nationalökonomie und Statistik (Journal of Economics and Statistics), 233 (3) (2013).

Cwik, Tobias and Volker Wieland (2011), "Keynesian Government Spending Multipliers and Spillovers in the Euro Area", Economic Policy 26, pp.493-549.

Deutsche Bank Research (2010), “Bail-out' for German Municipalities”, Research Briefing 25 November 2010.

Deutsche Bundesbank (2011), Monthly Report October 2011, 63 (10), Frankfurt a.M.

Deutsche Bundesbank (2012a), Monthly Report October 2012, 64 (10), Frankfurt a.M.

Deutsche Bundesbank (2012b), Monthly Report August 2012, 64 (8), Frankfurt a.M.

Domar, Evsey D. (1944), "The Burden of the Debt and International Income", American Economic Review, 34, pp. 789-827. 
Enderlein Henrik, Jobst Fiedler, Folke Schuppert, René Geissler, Florian Meinel and Camillo von Müller (2012), „Gutachten zur Umsetzung der grundgesetzlichen Schuldenbremse in Baden-Württemberg", Berlin: Hertie School of Governance.

Federal Ministry of Finance (2012), “Compendium on the Federation's Budget Rule as set out in Article 115 on the Basic Law", Berlin: Federal Ministry of Finance.

Feld, Lars P. (2010), „Sinnhaftigkeit und Effektivität der deutschen Schuldenbremse", Perspektiven der Wirtschaftspolitik, 11, pp. 226-245.

Feld, Lars P. (2011), „Krise der Staatsfinanzen: Institutionelle Rahmenbedingungen für eine solide Finanzpolitik“, in: Theresia Theurl (ed.), Institutionelle Hintergründe von Krisen, pp. 19-56, Berlin: Duncker \& Humblot.

Feld, Lars P. and Thushyanthan Baskaran (2010), "Federalism, Budget Deficits and Public Debt: On the Reform of Germany's Fiscal Constitution", Review of Law and Economics, 6 (3), pp. 365-393, DOI: 10.2202/1555-5879.1537.

Feld, Lars P. and Gebhard Kirchgässner (2008), "On the Effectiveness of Debt Brakes: The Swiss Experience", in: Reinhard Neck and Jan-Egbert Sturm (eds.), Sustainability of Public Debt, pp. 223-255, Cambridge/London: MIT Press.

Feld, Lars P. and Jan Schnellenbach (2013), Verzerrungen im bundesstaatlichen Finanzausgleich, Gutachten im Auftrag des Freistaats Bayern und des Landes Hessen, Freiburg.

Galmarini, Umberto, Leonzio Rizzo and Cecilia Testa (2007), "Local Finance Responsiveness to Federal Grants: The Role of the Debt", Economia del capitale umano, Istituzioni, incentivi e valutazioni, Pavia, Aule storiche Università, 13-14 settembre 2007.

Heinemann, Friedrich (2012), „Die Bundesländer wollen noch einmal prassen“, Wirtschaftswoche, 17 November 2012.

Heinemann Friedrich, Lars P. Feld, Benny Geys, Christoph Gröpl, Sebastian Hauptmeier and Alexander Kalb (2009), Der kommunale Kassenkredit zwischen Liquiditätssicherung und Missbrauchsgefahr, Baden-Baden: Nomos.

Hume, David (1741/1817), Philosophical Essays on Morals, Literature, and Politics, Vol. I, Philadelphia: Edward Earle.

Kempkes, Gerhard (2012), "Cyclical Adjustment in Fiscal Rules: Some Evidence on Real-Time Bias for EU-15 Countries", Deutsche Bundesbank Discussion Paper No. 15/2012.

Mikosch, Heiner F. and Silke Übelmesser (2007), „Staatsverschuldungsunterschiede im internationalen Vergleich und Schlussfolgerungen für Deutschland“, Perspektiven der Wirtschaftspolitik, 8, pp.309-334. 
Persson, Torsten and Lars E. O. Svensson (1989), "Why a Stubborn Conservative Would Run a Deficit: Policy with Time-Inconsistent Preferences", Quarterly Journal of Economics, 65, pp. 325-345.

Ricardo, David (1821/1923), „Grundsätze der Volkswirtschaft und Besteuerung", in: Heinrich Wagner (ed.), Sammlung sozialwissenschaftlicher Meister, Band 5, Jena: Gustav Fischer.

Roos, Micheal W.M. (2007), „Die makroökonomischen Wirkungen diskretionärer Fiskalpolitik in Deutschland - Was wissen wir empirisch?", Perspektiven der Wirtschaftspolitik, 8, pp. 293-308.

SACHVERSTÄNDIGENRAT ZUR BEGUTACHTUNG DER GESAMTWIRTSCHAFTLICHEN EnTwiCKLUNG (2010), Chancen für einen stabilen Aufschwung, Jahresgutachten 2010/11, Wiesbaden.

SACHVERSTÄNDigenRAT ZUR BegutaCHTUNG DER GeSAMTWIRTSCHAFTLICHEN ENTWICKLUNG (2011a), Herausforderungen des demografischen Wandels, Expertise im Auftrag der Bundesregierung, Wiesbaden.

SACHVERSTÄNDIGENRAT ZUR BEgUTACHTUNG DER GESAMTWIRTSCHAFTLICHEN ENTWICKLUNG (2011b), Verantwortung für Europa wahrnehmen, Jahresgutachten 2011/12, Wiesbaden.

Schaltegger, Christoph A. and Lars P. Feld (2009), "Do Large Cabinets Favor Large Governments?, Evidence on the Fiscal Commons Problem for Swiss Cantons", Journal of Public Economics, 93, pp.35-47.

Seitz, Helmut (1999), "Subnational Government Bailouts in Germany", Center for European Integration Studies Working Paper B 20.

Statistisches Bundesamt (2012), „Finanzen und Steuern - Steuerhaushalt 2011“, Fachreihe 14(4), Wiesbaden.

Tabellini, Guido and Alberto Alesina (1990), "Voting on the Budget Deficit", American Economic Review, 80, pp.37-49.

Tullock, Gordon (1959), "Problems with Majority Voting", Journal of Political Economy, 67, pp. 571-579.

\section{SUMMARY}

In 2009 Germany introduced a new fiscal rule in its Basic Law. It stipulates that the federal budget must be (structurally) close to balance from 2016 onwards and does not allow for (structural) budget deficits in the Laender (states') budgets after 2019. While the already existing debt brakes at the Laender level have relatively wide loopholes, six states do not even seriously consider the introduction of new fiscal rules. In fact, only 9 of the 16 Laender as well as the federal level 
passed binding consolidation plans. Despite historically high revenues in 2011, most states ran deficits and increased public debt. In this paper, we analyze the German debt brakes at the federal and the Laender levels and assess the probability that the German jurisdictions manage to comply with the constitutional requirements of its debt brake. 